\title{
Photochemical Mineralization of Terrigenous DOC to Dissolved Inorganic Carbon in Ocean
}

\section{Aarnos, Hanna}

2018-02

Aarnos , H , Gelinas , Y, Kasurinen , V , Gu , Y , Puupponen , V-M \& Vähätalo , A V 2018 , ' Photochemical Mineralization of Terrigenous DOC to Dissolved Inorganic Carbon in Ocean ' , Global Biogeochemical Cycles , vol. 32 , no. 2 , pp. 250-266 . https://doi.org/10.1002/2017GB005698

http://hdl.handle.net/10138/308195

https://doi.org/10.1002/2017GB005698

cc_by_nc_sa

publishedVersion

Downloaded from Helda, University of Helsinki institutional repository.

This is an electronic reprint of the original article.

This reprint may differ from the original in pagination and typographic detail.

Please cite the original version. 


\section{Global Biogeochemical Cycles}

\section{RESEARCH ARTICLE}

10.1002/2017GB005698

\begin{abstract}
Key Points:
- Photochemical reactions mineralize $45(31-58)$ Tg terrigenous DOC per year in the ocean and more than in inland waters

- Photochemical mineralization of tDOC requires 34 (25-43) million square kilometers of ocean.

- Seventy-one percent of tDOC is mineralized within 1 year and nearly half $(47 \%)$ of this mineralization of tDOC is caused by photochemical transformation
\end{abstract}

Supporting Information:

- Supporting Information S1

Correspondence to:

A. V. Vähätalo,

anssi.vahatalo@jyu.fi

Citation:

Aarnos, H., Gélinas, Y., Kasurinen, V., Gu, Y., Puupponen, V.-M., \& Vähätalo, A. V. (2018). Photochemical mineralization of terrigenous DOC to dissolved inorganic carbon in ocean. Global Biogeochemical Cycles, 32, 250-266. https://doi.org/10.1002/2017GB005698

Received 19 APR 2017 Accepted 18 JAN 2018 Accepted article online 24 JAN 2018 Published online 20 FEB 2018

(O2018. American Geophysical Union. All Rights Reserved.

\section{Photochemical Mineralization of Terrigenous DOC to Dissolved Inorganic Carbon in Ocean}

\author{
Hanna Aarnos ${ }^{1,2}$, Yves Gélinas ${ }^{3,4}$, Ville Kasurinen ${ }^{5,6,7}(\mathbb{D})$, Yufei Gu ${ }^{1}(\mathbb{D})$, Veli-Mikko Puupponen ${ }^{1}$, \\ and Anssi V. Vähätalo' 1 \\ ${ }^{1}$ Department of Biological and Environmental Science, University of Jyväskylä, Jyväskylä, Finland, ${ }^{2}$ Department of \\ Environmental Sciences, University of Helsinki, Helsinki, Finland, ${ }^{3}$ Geotop, Montreal, Quebec, Canada, ${ }^{4}$ Department of \\ Chemistry and Biochemistry, Concordia University, Montreal, Quebec, Canada, ${ }^{5}$ Department of Forest Sciences, University \\ of Helsinki, Helsinki, Finland, ${ }^{6}$ Department of Physics, University of Helsinki, Helsinki, Finland, ${ }^{7}$ Department of \\ Environmental and Biological Sciences, University of Eastern Finland, Kuopio, Finland
}

Abstract When terrigenous dissolved organic carbon (tDOC) rich in chromophoric dissolved organic matter (tCDOM) enters the ocean, solar radiation mineralizes it partially into dissolved inorganic carbon (DIC). This study addresses the amount and the rates of DIC photoproduction from tDOC and the area of ocean required to photomineralize tDOC. We collected water samples from 10 major rivers, mixed them with artificial seawater, and irradiated them with simulated solar radiation to measure DIC photoproduction and the photobleaching of tCDOM. The linear relationship between DIC photoproduction and tCDOM photobleaching was used to estimate the amount of photoproduced DIC from the tCDOM fluxes of the study rivers. Solar radiation was estimated to mineralize $12.5 \pm 3.7 \mathrm{Tg} \mathrm{C} \mathrm{yr}^{-1}$ (10 rivers) $^{-1}$ or $18 \pm 8 \%$ of tDOC flux. The irradiation experiments also approximated typical apparent spectral quantum yields for DIC photoproduction $\left(\phi_{\lambda}\right)$ over the entire lifetime of the tCDOM. Based on $\phi_{\lambda} s$ and the local solar irradiances in river plumes, the annual areal DIC photoproduction rates from tDOC were calculated to range from $52 \pm 4$

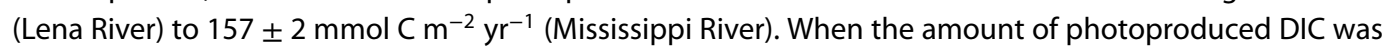
divided by the areal rate, $9.6 \pm 2.5 \times 10^{6} \mathrm{~km}^{2}$ of ocean was required for the photomineralization of tDOC from the study rivers. Extrapolation to the global tDOC flux yields $45(31-58) \mathrm{Tg}$ of photoproduced DIC per year in the river plumes that cover $34(25-43) \times 10^{6} \mathrm{~km}^{2}$ of the ocean.

\section{Introduction}

Riverine transport of terrigenous dissolved organic carbon (tDOC) from land to the ocean represents a major flux (248 $\mathrm{Tg} \mathrm{Cyr}^{-1}$ ) in the carbon cycle (Bauer et al., 2013; Cai, 2011; Hedges et al., 1997). Although riverine tDOC consists of thousands of compounds with a continuum of reactivities (Riedel et al., 2016; Vähätalo et al., 2010; Ward et al., 2013), it can be conceptually divided into the biologically labile (20 $\pm 16 \%$; mean \pm SD) and the remaining nonlabile $(80 \pm 16 \%$; mean \pm SD) fractions with different residence times in the ocean (Fichot \& Benner, 2014; Holmes et al., 2008; Søndergaard \& Middelboe, 1995). Close to river mouths, microbes mineralize labile riverine tDOC (Table 1) into dissolved inorganic carbon (DIC) within a couple of weeks (Fichot \& Benner, 2014; Holmes et al., 2008; Søndergaard \& Middelboe, 1995). The biologically nonlabile tDOC (Table 1) which is rich in terrestrial chromophoric dissolved organic matter (tCDOM) has a longer residence time and is transported offshore (Blough \& Del Vecchio, 2002; Vodacek et al., 1997). In the coastal ocean, tCDOM is primarily responsible for the absorption of solar ultraviolet and short-wavelength visible radiation that cause photochemical reactions (Bélanger et al., 2013; Johannessen et al., 2003; Taalba et al., 2013). These photochemical reactions are a major sink for nonlabile tDOC and tCDOM (Kieber et al., 1990; Miller \& Zepp, 1995).

Solar radiation can efficiently reduce the tCDOM content of surface waters through photobleaching (Lalonde et al., 2014; Riedel et al., 2016; Spencer et al., 2009; Vähätalo \& Wetzel, 2004, 2008; Vodacek et al., 1997). As much as $70 \%$ of the tCDOM content of the mixed layer can be photobleached during the transport of tCDOM across the continental shelf over a single summer stratification period (Vodacek et al., 1997). Simulated solar radiation can simultaneously photobleach nonlabile tCDOM and photomineralize $13-49 \%$ of nonlabile tDOC from major rivers into DIC (Lalonde et al., 2014; Miller \& Zepp, 1995; Riedel et al., 2016). This photomineralizable fraction of tDOC (Table 1) can potentially be exploited to estimate the amount of tDOC that is photochemically mineralized to DIC upon complete photobleaching of tCDOM in the ocean. Although photochemical reactions have long 
Table 1

Terms Related to tDOC in This Study

\begin{tabular}{|c|c|}
\hline Term & Definition \\
\hline Labile & A fraction that can be mineralized by microbes within a few weeks (unitless). \\
\hline Nonlabile & $\begin{array}{l}\text { A fraction that remains after microbial mineralization of labile } \\
\text { fraction (unitless). }\end{array}$ \\
\hline Photomineralizable fraction of $\mathrm{tDOC}$ & $\begin{array}{l}\text { The fraction of tDOC that can be mineralized by direct photochemical } \\
\text { reactions upon complete photobleaching of tCDOM (unitless). }\end{array}$ \\
\hline Photochemical reactivity of $\mathrm{tDOC}$ & $\begin{array}{l}\text { The tendency of tDOC to undergo photochemical mineralization (unit, mol } \\
\left(\text { mol absorbed photons }^{-1} \text { ). }\right.\end{array}$ \\
\hline Volumetric photomineralization rate & 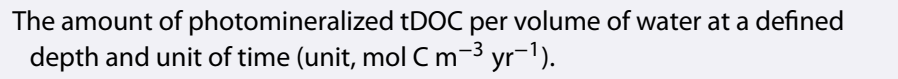 \\
\hline Areal photomineralization rate & 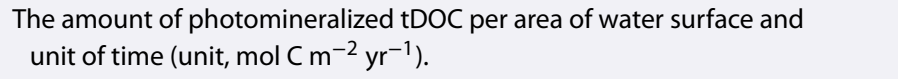 \\
\hline The amount of photomineralized tDOC & $\begin{array}{l}\text { The amount of photoproduced DIC from tDOC discharged by a river } \\
\text { per unit of time (unit, } \mathrm{g}\left(\text { river }^{-1} \mathrm{yr}^{-1}\right) \text {. }\end{array}$ \\
\hline $\begin{array}{l}\text { Area required for mineralization } \\
\text { of photomineralizable tDOC }\end{array}$ & $\begin{array}{l}\text { The area of ocean required to complete the photomineralization of tDOC } \\
\text { discharged by a river (unit, } \mathrm{m}^{2} \text { river }^{-1} \text { ). }\end{array}$ \\
\hline $\begin{array}{l}\text { The distance for photomineralization } \\
\text { of tDOC }\end{array}$ & $\begin{array}{l}\text { Approximates how far offshore tDOC is transported from river mouths } \\
\text { until the photomineralization is completed (unit, } m \text { ). }\end{array}$ \\
\hline
\end{tabular}

been recognized as a major sink for tDOC (Kieber et al., 1990; Miller \& Zepp, 1995), the amount of photoproduced DIC from tDOC in the ocean is still poorly known.

The rates of photochemical transformation per unit of volume or area (Table 1) (Aarnos et al., 2012; Powers \& Miller, 2015; White et al., 2010; Zhang et al., 2006) and the photochemical reactivity of DOC (Table 1) (Aarnos et al., 2012; Bélanger et al., 2006; White et al., 2010; Zhang et al., 2006) decrease offshore. Despite this decrease, the amount of phototransformed tDOC within river plumes (Table 1) increases toward the distal part of the plumes (Hernes \& Benner, 2003; Medeiros et al., 2015; Vodacek et al., 1997). The increase results from the mixing of river water and seawater as (i) the mixing of tCDOM-rich river water with low-CDOM seawater decreases the photochemical turnover time of tDOC per unit of area along offshore transport (Vodacek et al., 1997) and (ii) the advection of tDOC increases the surface water area available for the photochemical transformations. Typically, only $3.7 \%$ of the total land area is available for photochemical transformation of tDOC (Verpoorter et al., 2014), and this percentage is even lower for catchments dominated by rivers (e.g., the Amazon, Congo, Ganges-Brahmaputra, Mekong, and Mississippi). For example, photochemical transformation of tDOC plays a minor role in the Amazon River itself (Amon \& Benner, 1996), but its importance is remarkable in the river plume (Medeiros et al., 2015).

Currently, the amount of phototransformed DOC has been estimated for arbitrary sections of coastal ocean (Bélanger et al., 2006; Fichot \& Benner, 2014; Miller et al., 2002), and these estimates often include the phototransformation of both tDOC and marine DOC (Aarnos et al., 2012; Bélanger et al., 2006; Miller et al., 2002). The distribution of tDOC in the ocean can be traced with different proxies (e.g., with optical, molecular, and isotopic signatures) (Fichot \& Benner, 2014; Medeiros et al., 2017), but discriminating between the photochemical transformation of tDOC and that of marine DOC is challenging. In the Baltic Sea, for example, the estimated amount of photomineralized DOC exceeds the riverine flux of photoreactive tDOC to the coastal waters (Aarnos et al., 2012), suggesting that solar radiation photomineralizes both tDOC and marine DOC. To estimate the amount of phototransformed tDOC in an ocean, it is important to account for the phototransformation of tDOC across the entire river plume and, in particular, at the distal parts of river plumes, which are recognized as hot spots for the photochemical transformation of tDOC (Hernes \& Benner, 2003; Medeiros et al., 2015; Vodacek et al., 1997). There is an important gap in knowledge regarding the location and rates of tDOC photomineralization and the area of ocean surface water required to photomineralize tDOC (Table 1).

In this study, we estimate the amount of photomineralized tDOC and the area of surface ocean required to oxidize the photoreactive fraction of riverine tDOC delivered from major rivers, assuming that photobleaching is the only sink for tCDOM. To obtain these estimates, we conducted laboratory irradiations with water samples 
Table 2

The Coordinates and the Dates for the Water Samples Collected From the Rivers and the St. Lawrence Estuary (PSU Refers to the Practical Salinity Unit) and the Transport Time Between the Sampling and the Filtration in Helsinki

\begin{tabular}{|c|c|c|c|c|c|}
\hline & Sample & Latitude & Longitude & $\begin{array}{c}\text { Sampling } \\
\text { date }\end{array}$ & $\begin{array}{l}\text { Transport } \\
\text { time (days) }\end{array}$ \\
\hline \multirow[t]{13}{*}{ Rivers } & Rio Negro ${ }^{a}$ & $03^{\circ} 07^{\prime} 59^{\prime \prime} \mathrm{S}$ & $59^{\circ} 54^{\prime} 09^{\prime \prime} \mathrm{W}$ & 3 Jun 2010 & 82 \\
\hline & Rio Solimões ${ }^{a}$ & $03^{\circ} 07^{\prime} 58^{\prime \prime} \mathrm{S}$ & $59^{\circ} 54^{\prime} 04^{\prime \prime} \mathrm{W}$ & 3 Jun 2010 & 82 \\
\hline & Congo ${ }^{b}$ & $04^{\circ} 18^{\prime} 18^{\prime \prime S}$ & $15^{\circ} 28^{\prime} 32^{\prime \prime} \mathrm{E}$ & 01 May 09 & 25 \\
\hline & Congo ${ }^{b}$ & $04^{\circ} 20^{\prime} 18^{\prime \prime} \mathrm{S}$ & $15^{\circ} 11^{\prime} 13^{\prime \prime} \mathrm{E}$ & 2 May 2009 & 24 \\
\hline & Danube & $45^{\circ} 13^{\prime} 38^{\prime \prime} \mathrm{N}$ & $28^{\circ} 44^{\prime} 05^{\prime \prime} \mathrm{E}$ & 19 Apr 2010 & 21 \\
\hline & Ganges-Brahmaputra & $23^{\circ} 34^{\prime} 12^{\prime \prime} \mathrm{N}$ & $90^{\circ} 10^{\prime} 53^{\prime \prime} \mathrm{E}$ & 1 Oct 2009 & 58 \\
\hline & Lena & $71^{\circ} 54^{\prime} 14^{\prime \prime} \mathrm{N}$ & $127^{\circ} 15^{\prime} 16^{\prime \prime} \mathrm{E}$ & 16 Aug 2009 & 155 \\
\hline & Mekong & $11^{\circ} 33^{\prime} 28^{\prime \prime} \mathrm{N}$ & $104^{\circ} 56^{\prime} 53^{\prime \prime} \mathrm{E}$ & 21 Aug 2009 & 33 \\
\hline & Mississippi & $29^{\circ} 02^{\prime} 20^{\prime \prime} \mathrm{N}$ & $89^{\circ} 19^{\prime} 20^{\prime \prime} \mathrm{W}$ & 22 Apr 2009 & 34 \\
\hline & Paraná & $34^{\circ} 18^{\prime} 07^{\prime \prime} \mathrm{S}$ & $58^{\circ} 32^{\prime} 47^{\prime \prime} \mathrm{W}$ & 29 Mar 2009 & 18 \\
\hline & St. Lawrence & $46^{\circ} 54^{\prime} 45^{\prime \prime} \mathrm{N}$ & $70^{\circ} 52^{\prime} 32^{\prime \prime} \mathrm{W}$ & 12 Jun 2009 & 31 \\
\hline & Yangtze & $31^{\circ} 45^{\prime} 49^{\prime \prime} \mathrm{N}$ & $121^{\circ} 02^{\prime} 22^{\prime \prime} \mathrm{E}$ & 7 Sep 2009 & 16 \\
\hline & Salinity (PSU) & & & & \\
\hline St. Lawrence & 0.1 & $46^{\circ} 54^{\prime} 46^{\prime \prime} \mathrm{N}$ & $70^{\circ} 52^{\prime} 32^{\prime \prime} \mathrm{W}$ & 12 Jun 2009 & 27 \\
\hline \multirow[t]{6}{*}{ Estuary } & 5.3 & $47^{\circ} 10^{\prime} 49^{\prime \prime} \mathrm{N}$ & $70^{\circ} 37^{\prime} 16^{\prime \prime} \mathrm{W}$ & 12 Jun 2009 & 27 \\
\hline & 20.0 & $47^{\circ} 30^{\prime} 59^{\prime \prime} \mathrm{N}$ & $70^{\circ} 10^{\prime} 53^{\prime \prime} \mathrm{W}$ & 13 Jun 2009 & 26 \\
\hline & 22.0 & $47^{\circ} 55^{\prime} 16^{\prime \prime} \mathrm{N}$ & $69^{\circ} 4638^{\prime \prime} \mathrm{W}$ & 13 Jun 2009 & 26 \\
\hline & 28.7 & $48^{\circ} 15^{\prime} 54^{\prime \prime} \mathrm{N}$ & $69^{\circ} 21^{\prime} 08^{\prime \prime} \mathrm{W}$ & 10 Jun 2009 & 29 \\
\hline & 27.9 & $48^{\circ} 42^{\prime} 06^{\prime \prime} \mathrm{N}$ & $68^{\circ} 39^{\prime} 07^{\prime \prime} \mathrm{W}$ & 10 Jun 2009 & 29 \\
\hline & 30.7 & $49^{\circ} 25^{\prime} 22^{\prime \prime} \mathrm{N}$ & $66^{\circ} 19^{\prime} 29^{\prime \prime} \mathrm{W}$ & 09 Jun 2009 & 30 \\
\hline
\end{tabular}

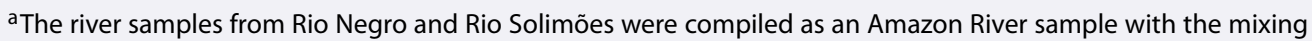
ratio of 1:4, respectively. ${ }^{\text {b}}$ The Congo River samples (twice $20-\mathrm{L}$ ) from two sampling locations were compiled as one Congo River sample.

collected from 10 major rivers and from the St. Lawrence Estuary. We then calculated the amounts of photomineralized DIC, the areal rates, and the area of the river plumes where photomineralization takes place.

\section{Material and Methods}

\subsection{Sample Collection}

The large rivers selected for this study (Table 2) drain 23\% of the land area on five continents, contribute to $33 \%$ of the freshwater discharge and 28\% of the tDOC flux to the ocean (Cauwet, 2002; Milliman \& Farnsworth, 2011; Raymond \& Spencer, 2014). The St. Lawrence Estuary was also sampled for the examination of photochemical transformation of DOC across its freshwater end to a salinity of 31 PSU (Table 2).

The samples from the St. Lawrence Estuary ( $1 \mathrm{~L}$; Table 2) were collected with Niskin bottles at a depth of $3 \mathrm{~m}$, filtered (precombusted $0.45 \mu \mathrm{m} \mathrm{GF/F} \mathrm{filter),} \mathrm{stored} \mathrm{in} \mathrm{amber} \mathrm{glass} \mathrm{bottles} \mathrm{and} \mathrm{sent} \mathrm{to} \mathrm{Helsinki,} \mathrm{Finland.} \mathrm{For}$ collection of river water samples $(40 \mathrm{~L}$ ), we shipped empty polyethylene containers (cleaned with detergent, $6 \% \mathrm{HCl}$, and ion-exchanged water, Millipore Milli-Q) to the local collaborators (see the Acknowledgements section). The samples were collected mostly from the main stem of rivers close to the river mouth, where the seasonal fluctuations in the quality of tDOC are expected to be the smallest (Creed et al. 2013). The river water samples were collected during the season of high discharge, which is the most important contributor to the annual tDOC flux (Table 2). The local collaborators filled the containers by immersing them below the surface in the center of the main stream, except for the Mississippi and the St. Lawrence River water samples that were collected with Niskin bottles at a depth of $3 \mathrm{~m}$. The river water samples were shipped as collected, in the dark, with a 32 day median transport time between the sampling sites and our laboratory in Helsinki. During transport (Table 2), indigenous microbes consumed the labile fraction of tDOC (e.g., 19\% of DOC in the St. Lawrence River sample, Lalonde et al., 2014). After arrival, the Rio Negro and Rio Solimões samples 
were mixed in a 1:4 ratio to obtain a representative sample of the Amazon River. The two samples from the Congo River were mixed in the same manner (1:1 ratio). The river waters were filtered through $1 \mu \mathrm{m}$ cartridges (a quick-rinsed membrane cartridge, Nuclepore, or the double layer of a track-etch polyester membrane filter cartridge, Graver Technologies) and kept in the dark at $5^{\circ} \mathrm{C}$ before the photochemical experiments.

Aliquots of the same river water samples have been examined earlier (Tables S2 and S3 in the supporting information) to show that the chromophores of iron can contribute to the TCDOM (several percent of tCDOM in the Congo and Amazon Rivers, for example) (Xiao et al., 2013) and that dissolved black carbon (DBC) contributes about $10 \%$ to tDOC in all rivers (Jaffé et al., 2013). Photomineralization leads to the preferential removal of the ${ }^{12} \mathrm{C}$-isotope from tDOC (Lalonde et al., 2014) and, together with biodegradation, decreases the contribution of DBC to tDOC to a level comparable to the concentrations measured in the deep ocean (Riedel et al., 2016). The DOM in the river water samples consisted of at least 7,838 distinct molecular formulas, of which about $1 / 3$ were detected in every waters sample (Wagner et al., 2015).

\subsection{Photochemical Experiments with Nonlabile DOC}

Irradiation experiments were conducted to estimate the typical photochemical reactivity of tDOC across its entire lifetime during transport from river mouths to the distal edge of river plumes. Our experimental design addressed three major hypotheses. (i) Microbes consume biologically labile tDOC close to river mouths and photochemical transformations concern primarily biologically modified nonlabile tDOC further offshore. Therefore, the irradiation experiments targeted nonlabile tDOC. (ii) The mixing of tDOC with seawater may change the photochemical reactivity of tDOC (Minor et al., 2006; White et al., 2010) and flocculate some terrigenous components (e.g., iron) present in river water (Asmala et al., 2014; Sholkovitz, 1976). Therefore, the river water samples were mixed with artificial DOC-free seawater and filtered prior to the irradiation experiments. (iii) The photochemical reactivity of tDOC decreases with the photobleaching of tCDOM along its offshore transport and becomes negligible upon complete photobleaching of tCDOM at the distal edges of river plumes. In order to approximate the average photochemical reactivity of $\mathrm{tDOC}$, the irradiation times were selected to photobleach about half of the tCDOM.

For the photochemical experiments, $1 \mu \mathrm{m}$ filtered river water was mixed (1:1 ratio) with artificial seawater (Kester et al., 1967) and further filtered through $0.2 \mu \mathrm{m}$ membrane filters (Supor-200, Pall). In the mixtures, the relative abundance of the different ions was similar to seawater but the salinity (16 PSU) was about half that of seawater. The seven St. Lawrence Estuary samples were not mixed with artificial seawater but apart from this, they were treated in the same way as the other water samples. Immediately following filtration, the background DIC was removed in custom-made gas exchange bottles $(500 \mathrm{~mL}$ ) by acidifying the water samples to $\mathrm{pH} 3$ with $1 \mathrm{M} \mathrm{HCl}$ and bubbling them with $\mathrm{CO}_{2}$-free air (Miller \& Zepp, 1995). The $\mathrm{pH}$ of water samples was then adjusted with $0.1 \mathrm{M} \mathrm{Na}_{2} \mathrm{~B}_{4} \mathrm{O}_{7}$ buffer to approximately $\mathrm{pH} 7-8$, as found in the ocean (Johannessen \& Miller, 2001). Aliquots were sealed into $12 \mathrm{~mL}$ tubes by ground-glass stoppers without headspace: two quartz tubes to be irradiated (one quartz tube for the St. Lawrence Estuary samples) and two $12 \mathrm{~mL}$ glass tubes either wrapped in aluminum foil (dark control) or kept in the dark in cold $\left(0^{\circ} \mathrm{C}\right)$ water (initial).

The quartz and the aluminum foil-wrapped dark tubes were exposed to simulated solar radiation (Atlas Suntest CPS+ Solar simulator, $765 \mathrm{~W} \mathrm{~m}^{-2}$ ) in a water bath regulated to $21^{\circ} \mathrm{C}$ with a Lauda RE 112 thermostat (supporting information). The dark controls were placed on the bottom of water bath, while the quartz tubes were immersed about $6 \mathrm{~cm}$ below the water surface and received simulated solar radiation corresponding to 23-25 days of the mean UV radiation received by the Earth's surface, when calculated from the Earth's annual global mean energy budget (Kiehl \& Trenberth, 1997), and accounting for the spectral irradiance of Suntest CPS+ and the ASTMG173-03 (American Society for Testing and Materials Standard G-173-03 derived from SMARTS version 2.9.2) solar reference spectrum.

After the irradiation, the concentration of DIC was determined in the initial, dark control, and irradiated water by injecting $750 \mu \mathrm{L}$ (seven injections per sample) into an acid bath and measuring the evolved $\mathrm{CO}_{2}$ (Salonen, 1981). The photochemical production of DIC was calculated as the difference between the DIC concentrations in the irradiated and the dark control samples. No significant difference was found between the DIC concentration in the initial samples and the dark controls, indicating negligible interference by dark chemical or biological processes on DIC photoproduction. The rest of the initial, dark, and irradiated samples were stored in the dark at $5^{\circ} \mathrm{C}$ for the measurement of CDOM. 


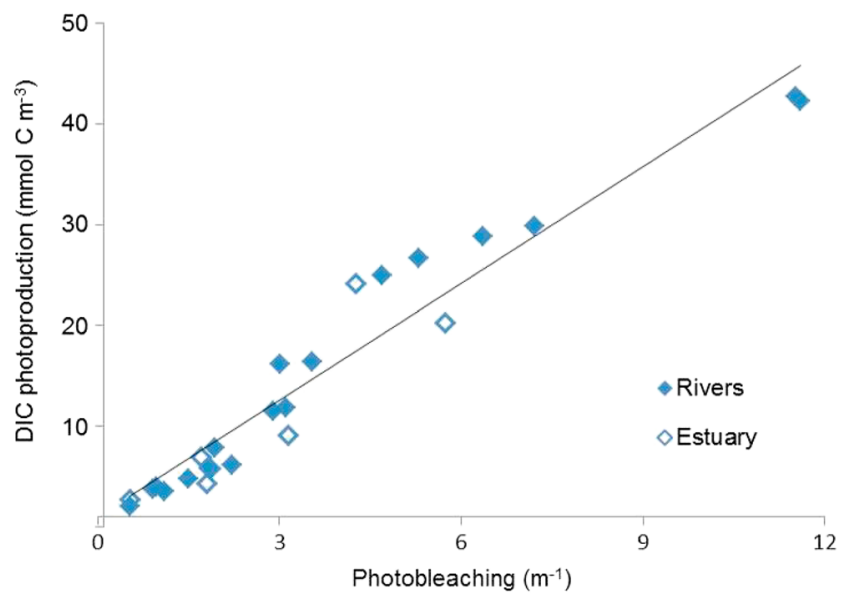

Figure 1. The dependence of DIC photoproduction on the tCDOM photobleaching expressed as a change in the absorption coefficient at $300 \mathrm{~nm}$. The blue diamonds show the measurements from river waters mixed with artificial seawater, and open diamonds show data from the salinity transect in the St. Lawrence Estuary (Table 3 ). The line shows a linear regression, DIC photoproduction $=4.02 \times$ photobleaching, fitted on the river water data $\left(R^{2}=0.96 ; n=18\right)$. The regression coefficient $( \pm \mathrm{SE}) 0.00402( \pm 0.00018) \mathrm{mol} \mathrm{C} \mathrm{m}{ }^{-2}$ is significantly different from zero $\left(p<0.001\right.$, tStat $\left._{1,9}=22.3\right)$. The linear regression equation without intercept was selected, because the model with intercept did not improve the coefficient of determination $\left(R^{2}=0.96\right)$ and the intercept 0.63 was not significantly different from zero $\left(p=0.66\right.$, Stat $\left._{1,8}=0.45\right)$. The model fitted to all data (Rivers and Estuary) was DIC photoproduction $=4.00$ photobleaching $\left(p<0.001\right.$, Stat $_{1,16}=23.0$, $\left.R^{2}=0.93\right)$.

\subsection{Absorption Spectrum for CDOM}

The spectral absorption by CDOM was measured with a UV-VIS spectrophotometer (Shimadzu UV-2550) using a $5 \mathrm{~cm}$ quartz cuvette. The apparent absorbance spectrum of samples and blanks (Millipore Milli-Q water) was obtained from two scans between 190 and $800 \mathrm{~nm}$ in $1 \mathrm{~nm}$ steps against an empty reference cell holder. The blank was subtracted from the sample and the resulting absorbance of $\mathrm{CDOM}\left(\mathrm{A}_{\mathrm{CDOM}, \lambda}\right)$ was converted to an absorption coefficient $\left(a_{\lambda}\right)$ by $2.303 \mathrm{~A}_{\mathrm{CDOM}, \lambda} / 0.05$ (Bricaud et al., 1981). To avoid potential bias resulting from scattering, the CDOM absorption spectra were corrected according to the equation proposed by Bricaud et al. (1981): $a_{\mathrm{CDOM}, \lambda}=a_{\lambda}-$ $a_{700}(\lambda / 700)$, where $a_{\mathrm{CDOM}, \lambda}$ is the corrected CDOM absorption coefficient at a wavelength $\lambda$; and $a_{\lambda}$ and $a_{700}$ refer to uncorrected CDOM absorption coefficients at $\lambda$ and at $700 \mathrm{~nm}$, respectively. The photobleaching of CDOM during the irradiation was calculated as the difference in absorption coefficients of $\mathrm{CDOM}$ at $300 \mathrm{~nm}\left(\mathrm{a}_{\mathrm{CDOM}, 300} ; \mathrm{m}^{-1}\right)$ between the dark controls and irradiated waters.

\subsection{Areal Rates of DIC Photoproduction Based On Apparent Quantum Yields (AQY)}

For the determination of the AQY spectrum for DIC photoproduction $\left(\phi_{\lambda}\right)$, the measured DIC photoproduction was divided by the number of photons absorbed by CDOM during the irradiation (see Aarnos et al., 2012; details in the supporting information). We assumed an exponential increase in $\phi_{\lambda}$ with decreasing wavelength:

$$
\phi_{\lambda}=c \mathrm{e}^{-d \lambda}
$$

where $c\left(\mathrm{~mol} \mathrm{C}\right.$ mol photons $\left.{ }^{-1}\right)$ and $d\left(\mathrm{~nm}^{-1}\right)$ are positive constants, and $\lambda$ is the wavelength $(\mathrm{nm})$. The parameters $c$ and $d$ in equation (1) were iterated by relating the amount of photoproduct (DIC) to the number of photons absorbed by CDOM through an unconstrained nonlinear optimization (the fminsearch function of Matlab R2013a) as in Aarnos et al. (2012), Vähätalo and Järvinen (2007), Vähätalo and Wetzel (2004), Vähätalo and Zepp (2005), and Vähätalo et al. $(2000,2003,2011)$, but in this work a Monte Carlo approach was used to assess the error in fittings and to select the best $\phi_{\lambda}$ from 1,000 fittings (Gu et al., 2017, supporting information).

An areal DIC photoproduction rate in river plumes $\left(p r ; m o l ~ C ~ ~ m^{-2} \mathrm{~d}^{-1}\right.$ ) was calculated according to Vähätalo et al. (2000):

$$
p r=\int_{\lambda_{\min }}^{\lambda_{\max }} \phi_{\lambda} Q_{\lambda}\left(a_{\mathrm{CDOM}, \lambda} a_{\mathrm{tot}, \lambda}^{-1}\right) \mathrm{d} \lambda
$$

where $\phi_{\lambda}$ is the determined AQY spectrum for DIC photoproduction; $Q_{\lambda}$ represents the spectrum of mean annual photon flux density at the river plumes (mol photons $\mathrm{m}^{-2} \mathrm{~d}^{-1} \mathrm{~nm}^{-1}$; Figure S7); $a_{\mathrm{CDOM}, \lambda} a_{\mathrm{tot}, \lambda}^{-1}$ (dimensionless) is a contribution of riverine tCDOM to the total absorption coefficient $a_{\mathrm{tot}, \lambda} \cdot a_{\mathrm{CDOM}, \lambda} a_{\mathrm{tot}, \lambda}^{-1}$ was approximated to be 1 (see section 4 for the associated error). The integration through $\lambda_{\min }$ to $\lambda_{\max }$ accounts for the wavelengths $(300-600 \mathrm{~nm}$ ) contributing to the DIC photoproduction. Annual DIC photoproduction rates were computed by multiplying the daily rate of $p r$ (equation (2)) by 365 . The $Q_{\lambda}$ for each river was calculated according to the computed mean annual global radiation at the ocean in front of the rivers over the years 1984 to 2000 (Hatzianastassiou et al., 2005) and the spectral reference solar irradiance (ASTMG173-03) from where the spectral form for $Q_{\lambda}$ was adapted (details in the supporting information).

\subsection{The Amount of Photoproduced DIC From tCDOM Flux}

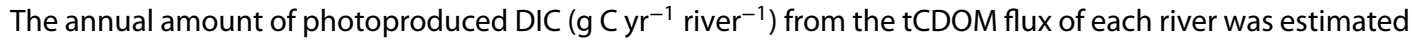
using a linear regression between DIC photoproduction $\left(\mathrm{mol} \mathrm{C} \mathrm{m}{ }^{-3}\right)$ and photobleaching of $\mathrm{tCDOM}\left(\mathrm{m}^{-1}\right)$ at a wavelength of $300 \mathrm{~nm}$ measured during the irradiation experiments (Figure 1). The regression coefficient (mol $\mathrm{C} \mathrm{m}^{-2}$, Figure 1) quantifies the amount of photoproduced DIC per photobleached tCDOM at $300 \mathrm{~nm}$. When the regression coefficient is multiplied by the amount of photobleached tCDOM from each river $\left(\mathrm{m}^{2} \mathrm{yr}^{-1}\right.$ river $\left.^{-1}\right)$, the product expresses the amount of photoproduced DIC from each river $\left(\mathrm{g} \mathrm{C} \mathrm{yr}^{-1} \mathrm{river}^{-1}\right)$. Carbon fluxes are 
Table 3

DIC Photoproduction (Mean $\pm S D^{\mathrm{a}}$ ) and the Photochemical Bleaching of CDOM During the Experimental Irradiations

\begin{tabular}{|c|c|c|c|c|}
\hline & Sample & $\begin{array}{c}\text { DIC } \\
\text { photoproduction } \\
\left(\mathrm{mmol} \mathrm{C} \mathrm{m}{ }^{-3}\right)\end{array}$ & $\begin{array}{c}\text { Photobleaching } \\
\text { of CDOM } \\
\left(\mathrm{m}^{-1}\right)\end{array}$ & (\%) \\
\hline \multirow[t]{12}{*}{ Rivers } & I Irradiation (39.1 h) & & & \\
\hline & Congo & $42.5 \pm 0.3$ & $11.56 \pm 0.05$ & $55 \pm 0$ \\
\hline & Mekong & $3.7 \pm 0.2$ & $1.01 \pm 0.13$ & $34 \pm 4$ \\
\hline & Mississippi & $16.3 \pm 0.2$ & $3.28 \pm 0.37$ & $45 \pm 5$ \\
\hline & Paraná & $6.0 \pm 0.3$ & $2.03 \pm 0.26$ & $43 \pm 5$ \\
\hline & St. Lawrence & $11.7 \pm 0.2$ & $3.00 \pm 0.15$ & $48 \pm 2$ \\
\hline & II. Irradiation (43.3 h) & & & \\
\hline & Amazon & $29.4 \pm 0.7$ & $6.79 \pm 0.60$ & $52 \pm 5$ \\
\hline & Danube & $7.2 \pm 0.9$ & $1.94 \pm 0.09$ & $45 \pm 2$ \\
\hline & Ganges-Brahmaputra & $1.9 \pm 0.1$ & $0.54 \pm 0.04$ & $41 \pm 3$ \\
\hline & Lena & $25.8 \pm 1.2$ & $4.99 \pm 0.43$ & $45 \pm 4$ \\
\hline & Yangtze & $4.4 \pm 0.5$ & $1.24 \pm 0.05$ & $41 \pm 2$ \\
\hline St. Lawrence & III. Irradiation (41.4 h) & & & \\
\hline \multirow[t]{7}{*}{ Estuary } & 0.1 PSU & $24.1 \pm 0.5$ & $4.27 \pm 0.16$ & $34 \pm 1$ \\
\hline & 5.3 PSU & $20.3 \pm 0.7$ & $5.73 \pm 0.20$ & $49 \pm 2$ \\
\hline & 20.0 PSU & $9.1 \pm 0.5$ & $3.14 \pm 0.04$ & $44 \pm 1$ \\
\hline & 22.0 PSU & $6.9 \pm 0.7$ & $1.71 \pm 0.38$ & $33 \pm 7$ \\
\hline & 28.7 PSU & $4.3 \pm 0.8$ & $1.81 \pm 0.49$ & $43 \pm 12$ \\
\hline & 27.9 PSU & $5.9 \pm 0.4$ & $1.87 \pm 0.40$ & $36 \pm 8$ \\
\hline & 30.7 PSU & $2.7 \pm 0.5$ & $0.54 \pm 0.09$ & $24 \pm 4$ \\
\hline
\end{tabular}

Notes. Photobleaching is expressed as a change in the absorption coefficients at wave-

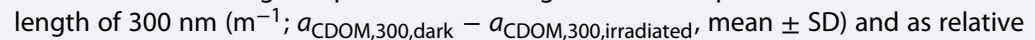
differences (\%; $\left.\left[a_{\mathrm{CDOM}, 300, \text { dark }}-a_{\mathrm{CDOM}, 300, \text { irradiated }}\right] a_{\mathrm{CDOM}, 300, \text { dark }}^{-1}\right)$ in the river samples and in the St. Lawrence Estuary samples.

an rivers, the error is the SD of two replicates. In the St. Lawrence Estuary, SD is calculated as the cumulative error in the replicated determinations of DIC $(n=7)$ and CDOM $(n=2)$. The data were derived with three separate $31.6,41.4$, or $43.3 \mathrm{~h}$ long irradiations.

either given as moles or grams and include always adequate conversion between the units. Photobleaching was assumed to be the only sink for tCDOM discharged in the ocean (Nelson \& Siegel, 2013; Vähätalo \& Wetzel, 2004, 2008; Vodacek et al., 1997). We assume that the amount of photobleached tCDOM from each river equals the tCDOM flux of each river $\left(\mathrm{m}^{2} \mathrm{yr}^{-1}\right.$ river $^{-1}$; see section 4 for the associated uncertainty).

The annual tCDOM fluxes for the Mississippi, St. Lawrence, and Lena Rivers were taken from earlier studies (Spencer et al., 2013; Stedmon et al., 2011). The published tCDOM fluxes reported at $350 \mathrm{~nm}$ or $375 \mathrm{~nm}$ were converted to the $300 \mathrm{~nm}$ wavelength using the following spectral slope coefficients: $16.4 \mu^{-1}$ for the Lena River (Stedmon et al., 2011), $17.6 \mu \mathrm{m}^{-1}$ for the Mississippi River, and $16.3 \mu^{-1}$ for the St. Lawrence River measured from our water samples. For the other rivers, tCDOM fluxes were calculated by multiplying the measured absorption coefficient at $300 \mathrm{~nm}\left(\mathrm{a}_{\mathrm{CDOM}, 300}\right)$ with the annual water discharge (Milliman \& Farnsworth, 2011).

\subsection{Area Needed for Photomineralization of Annual Riverine tDOC Flux in the Ocean}

To estimate the area of ocean surface waters required to photochemically mineralize the photoreactive fraction of riverine tDOC discharged by each river, the amount of photoproduced DIC from the tCDOM flux of

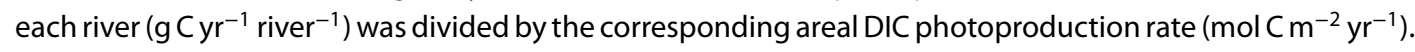
The areas were converted into semicircles. The radius of a semicircle approximates the distance from the river mouth required to photomineralize photoreactive $\mathrm{DDOC}$ flux, but without accounting for local geography or currents that disperse tDOC. 
Table 4

The Water Discharge, Absorption Coefficient at $300 \mathrm{~nm}\left(a_{\mathrm{CDOM}, 300}\right)$, the Fluxes of tDOC and $t C D O M$, the Amount of Photoproduced DIC From tCDOM Flux (DIC Prod), and the Fraction of Photomineralized tDOC Flux (DIC Prod:tDOC Flux)

\begin{tabular}{|c|c|c|c|c|c|c|}
\hline River & $\begin{array}{l}\text { Discharge } \\
\left(\mathrm{km}^{3} \mathrm{yr}^{-1}\right)\end{array}$ & $\begin{array}{c}a_{\mathrm{CDOM}, 300^{b}} \\
\left(\mathrm{~m}^{-1}\right)\end{array}$ & $\begin{array}{c}\mathrm{tDOC} \\
\text { flux } \\
\left(\mathrm{Tg}^{\mathrm{C}} \mathrm{Cyr^{-1 }}\right)\end{array}$ & $\begin{array}{c}\text { tCDOM } \\
\text { flux }{ }^{d} \\
\left(\mathrm{Tm}^{2} \mathrm{yr}^{-1}\right)\end{array}$ & 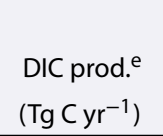 & $\begin{array}{c}\text { DIC prod. : } \\
\text { tDOC flux } \\
\text { (\%) }\end{array}$ \\
\hline Amazon & 6300 & $22.9 \pm 0.02$ & 37.50 & $144.55 \pm 0.15$ & $6.98 \pm 1.08$ & $19 \pm 3$ \\
\hline Congo & 1300 & $48.4 \pm 0.29$ & 10.15 & $62.92 \pm 0.38$ & $3.04 \pm 0.49$ & $30 \pm 5$ \\
\hline Danube & 210 & $7.6 \pm 0.03$ & 0.59 & $1.59 \pm 0.01$ & $0.08 \pm 0.02$ & $13 \pm 3$ \\
\hline Ganges-Brahmaputra & 1120 & $2.3 \pm 0.07$ & 3.60 & $2.60 \pm 0.08$ & $0.13 \pm 0.06$ & $3 \pm 2$ \\
\hline Lena & 520 & $21.0 \pm 0.02$ & 3.60 & $28.24 \pm 0.02$ & $1.36 \pm 0.24$ & $38 \pm 7$ \\
\hline Mekong & 550 & $4.9 \pm 0.01$ & 0.87 & $2.67 \pm 0.00$ & $0.13 \pm 0.04$ & $15 \pm 4$ \\
\hline Mississippi & 490 & $12.7 \pm 0.05$ & 3.50 & $5.06 \pm 0.02$ & $0.24 \pm 0.05$ & $7 \pm 1$ \\
\hline Parana & 530 & $8.9 \pm 0.07$ & 5.90 & $4.71 \pm 0.04$ & $0.23 \pm 0.05$ & $4 \pm 1$ \\
\hline St. Lawrence & 340 & $12.5 \pm 0.14$ & 1.55 & $1.43 \pm 0.02$ & $0.07 \pm 0.01$ & $4 \pm 1$ \\
\hline Yangtze & 900 & $5.3 \pm 0.24$ & 1.80 & $4.74 \pm 0.22$ & $0.23 \pm 0.07$ & $13 \pm 4$ \\
\hline Total & 12260 & & 69.06 & $258.52 \pm 0.93$ & $12.48 \pm 2.10$ & $18 \pm 4^{f}$ \\
\hline
\end{tabular}

${ }^{\mathrm{a}}$ Milliman and Farnsworth (2011). ${ }^{\mathrm{b}}$ Measured (SD = measurement uncertainty) from the river waters upon the arrival to our laboratory (Table 2), except a mean of our measurement $\left(24.9 \pm 0.02 \mathrm{~m}^{-1}\right)$ and $21.1 \mathrm{~m}^{-1}$ by Cao et al. 2016 for the Amazon River. 'Cauwet (2002), but updated for Amazon River by Coynel et al. (2005) and calculated for Mekong as the product of water discharge and DOC measured $\left(1.58 \mathrm{mg} \mathrm{C} \mathrm{L}^{-1}\right)$ upon the arrival of the water sample. ${ }^{\mathrm{d}}$ Calculated by

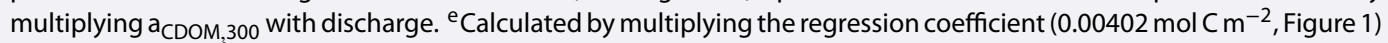
with tCDOM flux. ${ }^{\mathrm{f}} \mathrm{A}$ discharge weighted average.

\section{Results}

\subsection{Photochemical Production of DIC and Photobleaching of tCDOM}

The irradiations of river water samples (Table 2) mixed with artificial seawater produced DIC from terrigenous $\mathrm{DOC}(\mathrm{tDOC}$ ) and bleached terrigenous CDOM (tCDOM; Rivers in Table 3), at rates that varied between $1.9 \pm 0.1$ mmol C m ${ }^{-3} 43 \mathrm{~h}^{-1}$ (Ganges-Brahmaputra River; mean $\pm \mathrm{SD}$ ) and $42.5 \pm 0.3 \mathrm{mmol} \mathrm{C} \mathrm{m}^{-3} 39 \mathrm{~h}^{-1}$ (Congo River) (Table 3). The irradiations photobleached on average $45 \pm 3 \%$ of the tCDOM at $300 \mathrm{~nm}\left(\mathrm{a}_{\mathrm{CDOM}, 300}\right.$; Table 3). When expressed as an absorption coefficient at $300 \mathrm{~nm}$, photobleaching ranged from $0.54 \pm 0.04 \mathrm{~m}^{-1}$ (GangesBrahmaputra River) to $11.56 \pm 0.05 \mathrm{~m}^{-1}$ (Congo River; Table 3).

When sterile-filtered water samples collected from the St. Lawrence Estuary (Table 2) were exposed to the simulated solar radiation, DIC photoproduction and photobleaching were typically highest for the freshwater end-member and decreased with increasing salinities (Table 3). In both the St. Lawrence Estuary and the river water samples mixed with artificial seawater (Table 3), the DIC photoproduction was linearly dependent on tCDOM photobleaching despite large differences in the CDOM contents of water samples (Figure 1). The regression coefficient was $0.00402 \pm 0.00018 \mathrm{~mol} \mathrm{C} \mathrm{m}^{-2}$ ( \pm standard error) and $R^{2}$ was 0.96 for the river water samples (Figure 1).

\subsection{The Amount of Photoproduced DIC From the tCDOM Flux of Each River}

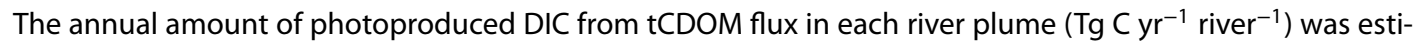
mated from the tCDOM fluxes (Table 4) and the regression coefficient between DIC photoproduction and tCDOM photobleaching (Figure 1). The photoproduction of DIC of the Amazon $\left(6.98 \pm 1.08 \mathrm{Tg} \mathrm{C} \mathrm{yr}^{-1}\right)$ and the

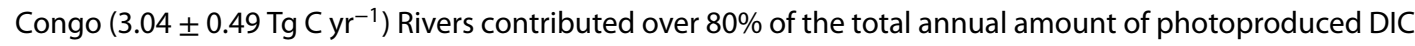
for the 10 rivers examined $\left(12.48 \pm 2.10 \mathrm{Tg} \mathrm{C} \mathrm{yr}^{-1} 10\right.$ rivers $^{-1}$; Table 4). The photomineralized fraction of riverine tDOC flux ranged from $3 \pm 2 \%$ to $38 \pm 7 \%$ among the studied rivers and the weighted average was $18 \pm 4 \%$ for the total flux of the 10 rivers examined (Table 4).

\subsection{Apparent Quantum Yields}

The photoproduced DIC (Table 3) was normalized against the photons absorbed by tCDOM for the determination of the spectral AQY for DIC photoproduction $\left(\phi_{\lambda}\right.$; equation (1) and Table 5). Table 5 reports the parameters $c$ and $d$ of equation (1) for the calculations of spectral $\phi_{\lambda}$ illustrated in Figure 2 . The $\phi_{\lambda}$ was highest for the Mississippi River tDOC, and lowest for the Ganges-Brahmaputra River tDOC, whether taken from the spectra (Figure 2$)$ or the AQYs at $330 \mathrm{~nm}\left(\phi_{330}\right.$, Table 5). The value of $\phi_{330}$ was similar in the St. Lawrence River water 
Table 5

Apparent Quantum Yields (AQY) for DIC Photoproduction $\left(\phi_{\lambda}\right)$ and the Annual DIC Photoproduction Rates (pr, Mean $\pm S D^{\mathrm{a}}$ )

\begin{tabular}{|c|c|c|c|c|c|c|}
\hline & Site & $\begin{array}{c}c \\
(\mathrm{~mol} \mathrm{C} \mathrm{mol} \\
\left.\text { photons }^{-1}\right)\end{array}$ & $\begin{array}{c}d \\
\left(\mathrm{~nm}^{-1}\right)\end{array}$ & $\begin{array}{c}\phi_{330} \\
(\mu \mathrm{mol} \mathrm{C} \mathrm{mol} \\
\left.\text { photons }^{-1}\right)\end{array}$ & CV\% & $\begin{array}{c}p r \\
(\mathrm{mmol} C \\
\left.\mathrm{m}^{-2} \mathrm{yr}^{-1}\right)\end{array}$ \\
\hline \multicolumn{7}{|l|}{ Rivers $^{\mathrm{b}}$} \\
\hline & Amazon & 1.404 & 0.0259 & 272 & 13 & $136 \pm 14$ \\
\hline & Congo & 1.418 & 0.0258 & 286 & 1 & $133 \pm 1$ \\
\hline & Danube & 1.395 & 0.0266 & 218 & 20 & $1 \pm 14$ \\
\hline & Ganges-Brahmaputra & 1.373 & 0.0281 & 129 & 12 & $54 \pm 7$ \\
\hline & Lena & 1.388 & 0.0257 & 289 & 9 & $52 \pm 4^{d}$ \\
\hline & Mekong 1.371 & 1.371 & 0.0273 & 165 & 3 & $76 \pm 2$ \\
\hline & Mississippi & 1.410 & 0.0253 & 335 & 1 & $157 \pm 2$ \\
\hline & Parana & 1.380 & 0.0271 & 179 & 14 & $70 \pm 7$ \\
\hline & St. Lawrence & 1.392 & 0.0261 & 250 & 5 & $75 \pm 3$ \\
\hline & Yangtze & 1.324 & 0.0271 & 172 & 40 & $54 \pm 16$ \\
\hline \multicolumn{7}{|c|}{ St Lawrence } \\
\hline \multicolumn{7}{|l|}{ Estuaryc } \\
\hline & 0.1 PSU & 1.397 & 0.0264 & 231 & 16 & $68 \pm 11$ \\
\hline & 5.3 PSU & 1.373 & 0.0264 & 226 & 12 & $67 \pm 8$ \\
\hline & 20.0 PSU & 1.386 & 0.0273 & 168 & 11 & $47 \pm 5$ \\
\hline & 22.0 PSU & 1.375 & 0.0278 & 140 & 13 & $38 \pm 5$ \\
\hline & 28.7 PSU & 1.373 & 0.0282 & 126 & 19 & $34 \pm 7$ \\
\hline & 27.9 PSU & 1.356 & 0.0278 & 142 & 9 & $39 \pm 4$ \\
\hline & 30.7 PSU & 1.380 & 0.0284 & 116 & 14 & $31 \pm 4$ \\
\hline
\end{tabular}

Note. The parameters $c$ and $d$ describe the AQY spectra for DIC photoproduction $\left(\phi_{\lambda}\right.$, equation (1)). $\phi_{330}$ is the apparent quantum yield for DIC photoproduction at the wavelength $330 \mathrm{~nm}$ calculated according to equation (1). The DIC photoproduction rates in river plumes and in the St. Lawrence Estuary are calculated based on equation (2) according to $\phi_{\lambda}$ and the local solar radiation (Figure S7 in the supporting information).

${ }^{a} \mathrm{SD}$ of replicates (Rivers) or uncertainty of determination (Estuary). ${ }^{\mathrm{b}}$ For the Rivers CV\% describes the coefficient of variability for $\phi_{330}$ based on two replicates. ' ${ }^{C}$ for the Estuary CV\% for $\phi_{330}$ is calculated as in Aarnos et al. (2012) as a propagation of error in the DIC photoproduction, the incident photon flux density, and the CDOM used for the determination of AQY. ${ }^{d}$ Assumes ice-free conditions.

mixed with artificial seawater and its freshwater end-member when accounting for the coefficient of variation related to the determination of $\phi_{\lambda}$ (Table 5). In the St. Lawrence Estuary, the values of $\phi_{330}$ decreased with increasing salinity to about half of the value for the freshwater end-member

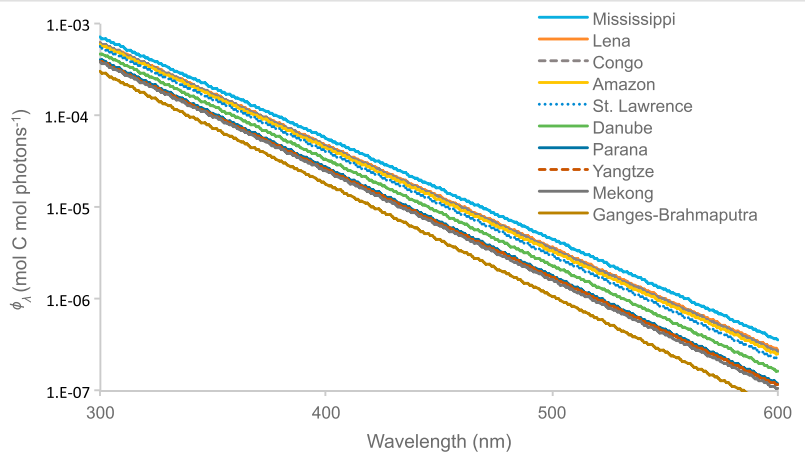

Figure 2. The apparent quantum yield spectra for DIC photoproduction $\left(\phi_{\lambda}\right)$ in river waters mixed with artificial seawater (Table 5; note the logarithmic scale on $y$ axis). The examined rivers are listed in the order of $\phi_{\lambda}$ from the largest to the smallest. $\left(\phi_{330}\right.$ in Table 5 and Figure 3).

\subsection{Annual Areal DIC Photoproduction Rates}

To calculate the annual areal DIC photoproduction rate in a river plume ( $p r$ in Table 5 and Figure 4), $\phi_{\lambda}$ was multiplied by the local annual solar photon flux density spectrum (equation (2) and Figure S7). These rates approximate the areal DIC photoproduction from tDOC at sites where half of the TCDOM has been photobleached. Similar to $\phi_{\lambda}$, the areal DIC photoproduction rate from tDOC was highest for the Mississippi River $\left(157 \pm 2 \mathrm{mmol} \mathrm{C} \mathrm{m}^{-2} \mathrm{yr}^{-1}\right.$; Table 5 and Figure 4). The lowest rate $\left(52 \pm 4 \mathrm{mmol} \mathrm{C} \mathrm{m}^{-2} \mathrm{yr}^{-1}\right)$ was calculated for the tDOC discharged by Lena River to the Laptev Sea, where the intensity of solar irradiation is low (Table 5, Figures 4 and S7).

\subsection{Area Needed for the Photomineralization of tCDOM Flux} in the Ocean

A division of the annual amount of photoproduced DIC from the TCDOM flux discharged by each river $\left(\operatorname{TgC~} r^{-1}\right.$ river $^{-1}$; Table 4$)$ by the corresponding areal 


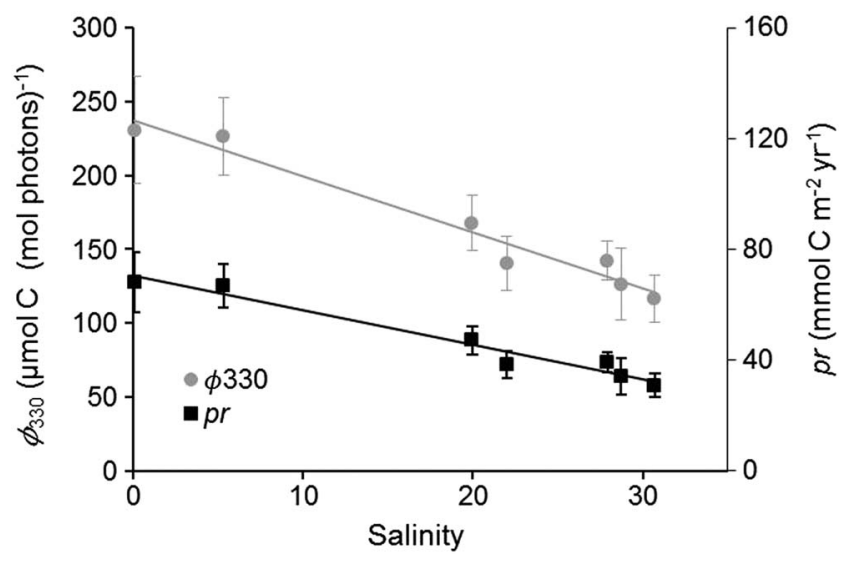

Figure 3. The apparent quantum yields $\left(\phi_{330} ; \mu \mathrm{mol} \mathrm{C} \mathrm{mol} \mathrm{photons}{ }^{-1}\right.$ at $330 \mathrm{~nm}$ ) and the annual areal DIC photoproduction rates ( $p r ; \mathrm{mmol}$ $\mathrm{C} \mathrm{m}^{-2} \mathrm{yr}^{-1}$ ) along the salinity transect in the St. Lawrence Estuary. The lines refer to linear fit $\left(R^{2}=0.95\right)$ between salinity and $\phi_{330}$ or $p r$. Error bars calculated as described in Table 5.
DIC photoproduction rate ( $\mathrm{mol} \mathrm{C} \mathrm{m}^{-2} \mathrm{yr}^{-1}$; Table 5 and Figure 4) provides an estimate of the ocean surface area required to completely photomineralize the photomineralizable fraction of $\mathrm{tDOC}$ (Table 6). The area was largest for the Amazon River $\left(4.3 \pm 1.1 \times 10^{6} \mathrm{~km}^{2}\right)$ and smallest for the St. Lawrence River $\left(76,000 \pm 19,000 \mathrm{~km}^{2}\right.$; Table 6). To estimate how far offshore the plume of riverine tCDOM extends until its photoreactive components are photochemically mineralized to DIC, we assumed there were semicircle-shaped river plumes, whose radii correspond to the distance required to completely photomineralize the photoreactive tDOC. These distances ranged from $221 \pm 54 \mathrm{~km}$ (St. Lawrence River) to $1652 \pm 422$ km (Amazon River; Table 6). Although the results in Table 6 represent a simplified view of the photomineralization and dispersion of $\mathrm{tDOC}$, they indicate that the photomineralization of tDOC fluxes from large rivers takes place mostly within a few hundred kilometers $(383 \pm 160 \mathrm{~km}$; median \pm SD) from the river mouths for most rivers studied in this work, except for rivers with the two largest discharges (the Amazon and Congo Rivers), and an Arctic river (Lena River).

\section{Discussion}

The discussion estimates first the annual amount of photoproduced DIC from the tDOC fluxes (sections 4.1-4.6). The second theme assesses the annual areal rates of DIC photoproduction in river plumes (section 4.7). At the end, the discussion evaluates the area of ocean needed to photomineralize tDOC (section 4.8).

\subsection{The Amount of Photochemically Mineralized tDOC in the Ocean}

This study estimates that photochemical reactions mineralize $12.5 \pm 2 \mathrm{Tg} \mathrm{C} \mathrm{yr}^{-1}$ or $18 \pm 4 \%$, of the tDOC flux in the plumes of the 10 rivers (Table 4). The uncertainty of estimates reported in Table 4 is derived from the propagation of the analytical errors (Table 5) and the regression statistics (Figure 1). Below we evaluate other uncertainties that are associated with our calculations and provide an estimate for the annual DIC photoproduction from tDOC in the global ocean.

\subsection{Photobleaching of tCDOM-A Good Proxy for DIC Photoproduction}

In this study, the amounts of photochemically mineralized tDOC in river plumes (Table 4) are estimated using the regression between DIC photoproduction and photobleaching (Figure 1). This relationship has high $R^{2}$ (0.96) and the standard error of regression coefficient is small (4.5\%; Figure 1). In comparison, the coefficient of variation (29\%) and the standard error $\left(21 \mu \mathrm{mol} \mathrm{C} \mathrm{mol} \mathrm{photons} \mathrm{m}^{-1}=9.2 \%\right)$ is larger for the mean $\phi_{330}$ $\left(230 \mu \mathrm{mol} \mathrm{C} \mathrm{mol} \mathrm{photons}{ }^{-1}\right)$ determined for the same 10 samples (Table 5). This comparison suggests that DIC photoproduction from tDOC is more

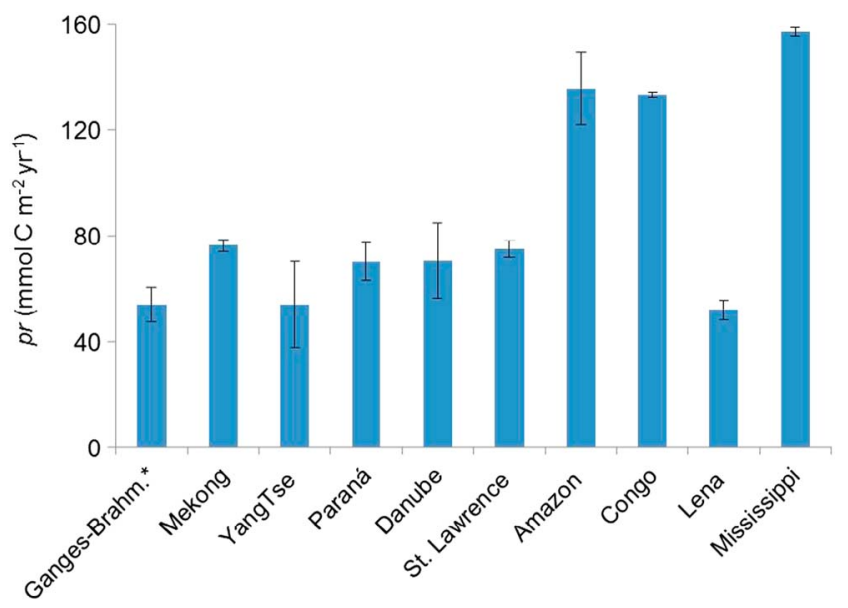

Figure 4. The annual areal DIC photoproduction rates from tDOC in river plumes ( $p r$ in Table 5). The rates are arranged in the order of increasing $\phi_{\lambda} \mathrm{s}$ (as in Figure 2). Error bars describe the standard deviation of $\mathrm{pr}$ $(n=2)$. Asterisk symbol $=$ Ganges-Brahmaputra River. closely related to the photobleaching of tCDOM than to the amount of photons (or energy) absorbed by tCDOM, which is used to calculate the AQYs. Photobleaching is tightly linked to the photoproduction of $\mathrm{CO}_{2}$ (this study) and other low molecular weight carbonyl compounds (Bertilsson \& Tranvik, 2000; Kieber et al., 1990; Miller \& Moran, 1997) indicating that the photoproduction of carbonyl compounds is mechanistically coupled to photobleaching. As conjugated carbonyl groups are chromophores in DOM (Chen et al., 2002; Korshin et al., 1997), the photochemical scission of carbonyl compounds (such as DIC, CO, and organic acids) represents a plausible CDOM photobleaching pathway. Photobleaching and DIC photoproduction associate with the loss of aromatic groups (Riedel et al., 2016), which are the most important chromophores in DOM (Chen et al., 2002; Korshin et al., 1997). For example, solar radiation can mineralize the carbon atoms of aromatic rings to DIC, which is a direct evidence for a simultaneous photobleaching and DIC photoproduction (Vähätalo et al., 1999). The mechanistic coupling between the photoproduction of carbonyl compounds and the photochemical destruction of chromophoric moieties in DOM makes photobleaching a useful proxy for the photoproduction of DIC and other carbonyl compounds. 
Table 6

The Area $\left(A ; \mathrm{km}^{2}\right)$ and Distance $(r ; \mathrm{km})$ Required for the Photomineralization of Photoreactive $t D O C$ Flux in Coastal Ocean (Mean $\pm S D^{\text {a) }}$

\begin{tabular}{|c|c|c|c|}
\hline River & $\begin{array}{c}\text { Photomineralization area }{ }^{b} \\
\text { for tDOC } \\
\left(10^{3} \mathrm{~km}^{2}\right)\end{array}$ & & $\begin{array}{l}\text { Photomineralization distance } \\
\text { for tDOC } \\
(\mathrm{km})\end{array}$ \\
\hline Amazon & $4,286 \pm 1,096$ & & $1,652 \pm 422$ \\
\hline Congo & $1,899 \pm 318$ & & $1,099 \pm 184$ \\
\hline Danube & $91 \pm 38$ & & $240 \pm 100$ \\
\hline Ganges-Brahmaputra & $194 \pm 115$ & & $351 \pm 209$ \\
\hline Lena & $2,186 \pm 533$ & & $1,180 \pm 288$ \\
\hline Mekong & $141 \pm 46$ & & $299 \pm 99$ \\
\hline Mississippi & $130 \pm 26$ & & $287 \pm 58$ \\
\hline Parana & $270 \pm 89$ & & $415 \pm 136$ \\
\hline St. Lawrence & $76 \pm 19$ & & $221 \pm 54$ \\
\hline Yangtze & $352 \pm 209$ & & $474 \pm 282$ \\
\hline Total & $9,624 \pm 2,489$ & Median & $383 \pm 160$ \\
\hline
\end{tabular}

${ }^{\text {a }} \mathrm{SD}$ is calculated as propagation of uncertainty related to the areal DIC photoproduction rate ( $p r$ in Table 5) and to the amount of photoproduced DIC from tCDOM flux (DIC prod. in Table 4). ${ }^{b}$ Calculated by dividing the annual amount of photoproduced DIC from TCDOM flux (Table 4) with the areal DIC photoproduction rate ( $p r$; Table 5). ${ }^{c} r=(2 A / \pi)^{0.5}$ assuming that tCDOM flux spreads uniformly into a semicircle-shaped area around the river mouth.

\subsection{Photobleaching as a Sink of tCDOM}

Our estimate for the amount of photomineralized tDOC is based on the assumption that photobleaching is the only sink for riverine tCDOM. Experimental irradiations can completely photobleach tCDOM from the rivers examined in this study (Lalonde et al., 2014; Miller \& Zepp, 1995; Riedel et al., 2016; Spencer et al., 2009). Photobleaching is also the primary sink of CDOM in the mixed layer of surface ocean waters (Nelson et al., 1998; Shank et al., 2010; Swan et al., 2012; Vähätalo \& Wetzel, 2004; Vodacek et al., 1997). A fraction of the tCDOM flux can also be transported below the mixed layer to remain in dark waters above a pycnocline for a short ( $<1$ year) period of time (Fichot \& Benner, 2014; Vodacek et al., 1997), but the seasonal deepening of mixed layer eventually reintroduces this CDOM into the mixed layer where it is eventually photobleached (Nelson et al., 1998). While about $1.7 \mathrm{Tg} \mathrm{Cyr}^{-1}$ of tDOC discharged by Arctic rivers (or $0.7 \%$ of global tDOC flux) is exported into the North Atlantic Deep Water and is therefore shielded from photobleaching for hundreds of years (Benner et al., 2005), the remaining $99.3 \%$ is susceptible to photobleaching, likely within the first year in the ocean surface waters. Indeed, tCDOM can be rapidly transported (within weeks or months) to the edge of river plumes (Coles et al., 2013; Fichot \& Benner, 2014) where photobleaching of CDOM can be completed within days-weeks (Nelson et al., 1998; Swan et al., 2012; Vodacek et al., 1997).

Other competing sinks for the nonlabile tDOC and tCDOM pools also exist, in addition to photobleaching. Biodegradation of nonlabile tDOC can also reduce the abundance of tCDOM and thus cause biobleaching. Microbes can biobleach tCDOM in fresh waters (Koehler et al., 2012; Vähätalo \& Wetzel, 2004, 2008), but the biobleaching rates decrease upon mixing of tCDOM with seawater (Figures 4 and 5 in Vähätalo \&Wetzel, 2004). In the ocean, microbial metabolism is often considered to be a source rather than a sink of CDOM (Jørgensen et al., 2014). In the deep dark ocean, the estimated turnover time of CDOM is 634 years (Catalá et al., 2015), indicating very slow biobleaching rates. Thus, it is not always clear whether microbial metabolism is a sink or a source of tCDOM in marine waters, but it is likely that microbes biobleach tCDOM when they consume nonlabile tDOC rich in tCDOM (Koehler et al., 2012; Vähätalo \& Wetzel, 2004, 2008). Microbes mineralized $12-25 \%$ of nonlabile tDOC from our river water samples during 1 year (Table S3). If this consumption of tDOC is associated with biobleaching (Koehler et al., 2012), it may cause a systematic reduction (roughly estimated at about $<20 \%$ ) in the amount of nonlabile tCDOM to be photobleached and thus in the DIC production from $\mathrm{tDOC}$ in the ocean.

\section{4. tCDOM Fluxes}

Our DIC production estimates from tDOC in river plumes also depend on tCDOM fluxes. For most rivers, tCDOM fluxes were estimated by multiplying the amount of nonlabile tCDOM measured in this study 
$\left(\mathrm{a}_{\mathrm{CDOM}, 300}\right.$; Table 4) and the annual water discharges (Table 4 from Milliman \& Farnsworth, 2011). For the Lena, Mississippi, and St. Lawrence Rivers, we used published tCDOM fluxes. If we would have treated these rivers like the others, our simple multiplication method would have given a collective tCDOM flux of $20.7 \mathrm{Tm}^{2} \mathrm{yr}^{-1}$, which corresponds to $56 \%$ of the literature-based estimate for these rivers ( $37.2 \mathrm{Tm}^{2} \mathrm{yr}^{-1}$ (Stedmon et al., 2011; Spencer et al., 2013). The tCDOM fluxes are not available for the Amazon and Congo Rivers, but the absorption coefficients of CDOM at $300 \mathrm{~nm}\left(\mathrm{a}_{\mathrm{CDOM}, 300}\right)$ measured in this study can be compared to those obtained in previous work. For the Congo River, our $a_{\mathrm{CDOM}, 300}$ is $48.4 \mathrm{~m}^{-1}$ (Table 4), corresponding to $53 \%$ of the value of $92.09 \mathrm{~m}^{-1}$ reported by Spencer et al. (2009). For the Amazon River, we used $a_{\mathrm{CDOM}, 300}$ value of $22.9 \mathrm{~m}^{-1}$, which is $8.5 \%$ larger than the $21.1 \mathrm{~m}^{-1}$ value measured at the mouth of the river (Cao et al., 2016). A use of $a_{\mathrm{CDOM}, 300}$ estimates from literature (Cao et al., 2016; Spencer et al., 2009) would have lead to a closer calculated DIC production from tDOC for the Congo (5.78 $\mathrm{Tg} \mathrm{C} \mathrm{yr}^{-1}$ ) and Amazon (6.43 $\mathrm{Tg} \mathrm{C} \mathrm{yr}^{-1}$ ) Rivers compared to the values listed in Table 4. The comparison of our rough estimates of tCDOM fluxes to these available in the literature (Cao et al., 2016; Spencer et al., 2009, 2013; Stedmon et al., 2011) yields differences that range from a 47\% underestimation to a $9 \%$ overestimation in tCDOM fluxes and thus in the amounts of photoproduced DIC. These differences in our tCDOM fluxes may come from natural interannual or seasonal variability in tCDOM fluxes. It is likely that biobleaching decreased the $a_{\mathrm{CDOM}, 300}$ values during the transportation of the samples. If this biobleaching was similar to the loss of tDOC during the transportation (Lalonde et al., 2014), the amounts of photochemically produced DIC from tDOC are underestimated by about $<20 \%$. The impact of biobleaching on our estimated DIC production rates from tDOC (Table 4) is likely low, because the overestimate caused by biobleaching in the ocean is probably compensated by the underestimate derived from biobleaching during the transportation of our samples.

\subsection{Uncertainty and Global Estimate for the Amount of Photochemically Mineralized tDOC in the Ocean \\ In this study, the uncertainty in tCDOM fluxes exceeds the analytical and statistical error reported in Table 4. We estimate that the uncertainty in TCDOM fluxes increases the uncertainty in the calculated amounts of tDOC photomineralized by about $\pm 30 \%$ when examined collectively for all rivers, but uncertainty for individual rivers can be even larger. Accounting for this uncertainty, the amount of photochemically mineralized tDOC amounts to $12.5 \pm 3.7 \mathrm{TgC}^{-1}$, or $18 \pm 8 \%$ of the tDOC flux from the 10 rivers.}

As the $\mathrm{tCDOM}$ fluxes represent the largest source of uncertainty in our estimate, we also used another tCDOM flux-independent method to estimate DIC photoproduction from nonlabile tDOC. The photomineralizable fraction of tDOC was measured in a previous work for the same river water samples examined in this study (Lalonde et al., 2014; Riedel et al., 2016). The photomineralizable fraction of nonlabile tDOC ranged from 16\% to $49 \%$ in the different river water samples in a laboratory study (Table S2). If the same fraction of nonlabile tDOC is photochemically mineralized in the ocean, the DIC photoproduction from nonlabile tDOC in the 10 rivers amounts to 18.7-19.7 $\mathrm{Tg} \mathrm{C} \mathrm{yr}^{-1}$ (Table S2). Correcting for the competing biobleaching of tCDOM in the ocean ( $20 \% \mathrm{yr}^{-1}$; Riedel et al., 2016), the DIC photoproduction from the nonlabile tDOC of 10 rivers decreases

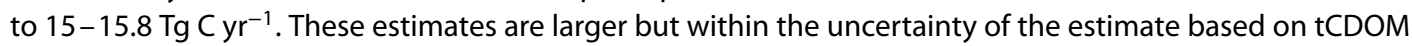
fluxes $\left(12.5 \pm 3.7 \mathrm{TgC}^{-1}\right)$. The possible differences between the results obtained using the two methods may arise from differences in experimental conditions. In this study, (i) the nonlabile tDOC was transferred into a seawater matrix, (ii) irradiated at $21^{\circ} \mathrm{C}$, (iii) the mineralization of tDOC was measured as the production of DIC and related to photobleaching of $a_{\mathrm{CDOM}, 300}$. Finally, (iv) the latter relationship was multiplied by the tCDOM flux to obtain $12.5 \mathrm{Tg} \mathrm{C} \mathrm{yr}^{-1}$ DIC photoproduction from nonlabile tDOC (Table 4). Lalonde et al. (2014) and Riedel et al. (2016) (i) used filtered river water directly, (ii) irradiated at $25^{\circ} \mathrm{C}$, (iii) measured the mineralization as the loss of DOC, (iv) which was directly related to the nonlabile tDOC flux (Table S2). The potential explanations for the differences in the estimates (Tables S2 and 4) are (i) matrix effects (river water versus seawater), (ii) the difference in the irradiation temperature, (iii) potential irradiation-induced flocculation of tDOC in Lalonde et al. (2014) and Riedel et al. (2016) versus true mineralization to $\mathrm{CO}_{2}$ in this study, and (iv) an error in the estimated tCDOM flux in this study.

To upscale our results from the 10 rivers to global fluxes, we first evaluate the global representativeness of the rivers studied in this work. The volume averaged concentration of DOC in the rivers examined in this study is $5.6 \mathrm{mg} \mathrm{CL}^{-1}\left(=6.91 \times 10^{13} \mathrm{~g} \mathrm{Cyr}^{-1} / 1.226 \times 10^{13} \mathrm{~m}^{3} \mathrm{yr}^{-1}\right.$ from Table 4), similar to the mean DOC concentration (5.75 $\mathrm{mg} \mathrm{C} \mathrm{L}^{-1}$ ) in the world's rivers (Meybeck, 1982) and to the mean DOC concentration $\left(5.7 \mathrm{mg} \mathrm{C} \mathrm{L}^{-1}\right.$ ) measured in 7,500 lakes distributed over six continents (Sobek et al., 2007). Four of the rivers examined in this study (Amazon, Congo, Paraná, and Lena Rivers) account for the largest tDOC fluxes to the ocean (Raymond \& Spencer, 2014). In the same study, the Mississippi and Ganges-Brahmaputra Rivers are also listed among the 


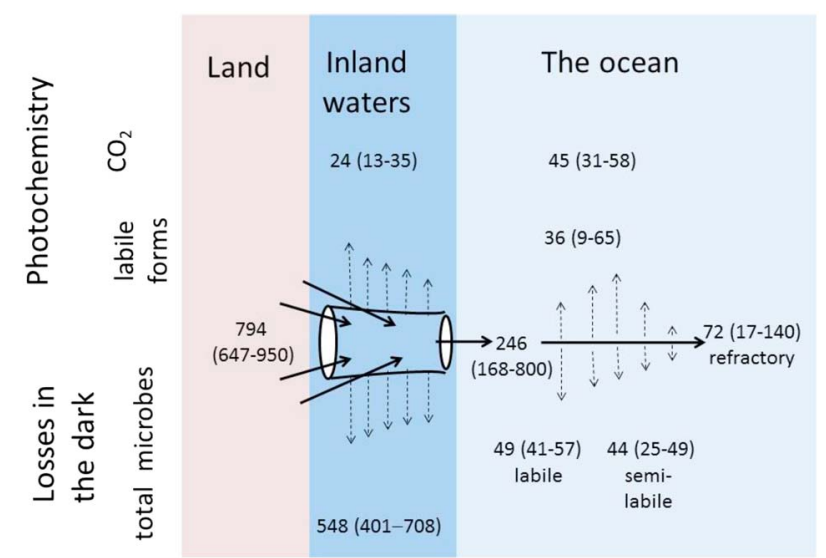

Figure 5. Global fluxes of tDOC across the aquatic continuum from land to the ocean. The transportation and transformations of tDOC are shown with solid and dotted arrows, respectively. The numbers refer

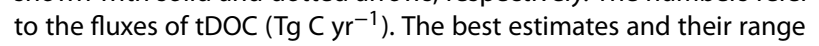
of uncertainty given in brackets are explained in the supporting information. Transport: 794 (647-950) from land to inland waters, 246 (168-800) from inland waters to the ocean. Photochemistry: 24 (15-35) DIC photoproduction in inland waters, 45 (31-58) DIC photoproduction in the ocean, $36(9-65)$ photoproduction of labile tDOC in the ocean. Microbial mineralization in the ocean: 49 (41-57) labile tDOC, 44 (25-49) semilabile tDOC. Other processes: $548(401-708)$ total loss in inland waters, $72(17-140)$ refractory tDOC that survived photochemical and microbial mineralization during its first year in the ocean. top 10 rivers with the highest tDOC fluxes. The others (Yangtze, Mekong, and Danube Rivers) are within the top 20. The rivers examined in this study span from high to low latitudes and drain major biomes on five continents, excluding Australia and Antarctica, which contribute little to the global tDOC flux. As the rivers examined in this study are responsible for $28 \%$ of tDOC flux to the global coastal ocean (69.1 $\mathrm{Tg} \mathrm{C} \mathrm{yr}^{-1}$ (Table 4) versus $246 \mathrm{Tg} \mathrm{C} \mathrm{yr}^{-1}$, Cai, 2011), we upscaled the cumulative results from our study rivers by multiplying them by $3.56\left(=0.28^{-1}\right)$ to estimate the global fluxes, leading to a DIC photoproduction

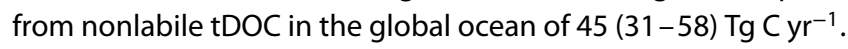

\subsection{Photochemical Mineralization of tDOC in the Ocean Versus Other Global tDoC Fluxes}

This study estimates that the amount of $\mathrm{tDOC}$ mineralized by solar radiation is higher in the ocean $\left(45(31-58) \mathrm{Tg} \mathrm{C} \mathrm{yr}^{-1}\right)$ than in inland waters $(24(13-35)$ $\mathrm{Tg} \mathrm{C} \mathrm{yr}{ }^{-1}$; Koehler et al., 2014; Figure 5 and the supporting information). Photochemical reactions mineralize a larger percentage of imported tDOC in the ocean $\left(18 \%=45 / 246 \mathrm{Tg} \mathrm{C} \mathrm{yr}^{-1}\right)$ than in the inland waters $(3 \%=24 / 794$

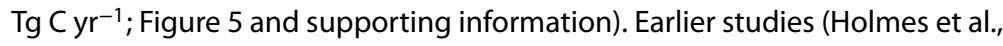
2008; Søndergaard \& Middelboe, 1995) reported that $20 \pm 16 \%$ of riverine tDOC (or 49 (41-57) $\mathrm{Tg} \mathrm{C} \mathrm{yr}^{-1}$; Figure 5) consists of labile tDOC and is biologically mineralized within a few weeks in the proximity of river mouths. Based on earlier 1 year long bioassays (Riedel et al., 2016), 44 (25-49) Tg C yr ${ }^{-1}$ of nonlabile tDOC is expected to be mineralized biologically within its first year in the ocean (semilabile in Figure 5 and Table S3, supporting information). Based on the ratios of photoproduced labile DOC to photoproduced DIC (Cory et al., 2014; Pullin et al., 2004; Vähätalo et al., 2003), sunlight-induced reactions transform $36(9-65) \mathrm{Tg} \mathrm{C} \mathrm{yr}^{-1}$ of nonlabile tDOC into labile forms (Figure 5 and supporting information). Thus, we estimate that photochemical reactions mineralize a total of

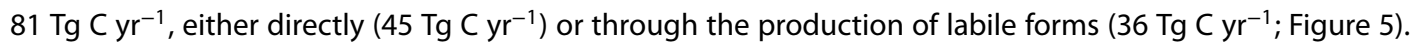
This amount of photochemical mineralization corresponds to $87 \%$ of tDOC mineralized by microbes during the first-year residence of tDOC in the ocean $\left(49+44=93 \mathrm{Tg} \mathrm{Cyr}^{-1}\right.$; Figure 5). The corresponding value is $67 \%$ for tDOC in the Mississippi River plume during its $2-3$ month residence time on the Louisiana shelf, where $\sim 50 \%$ of tDOC is mineralized (Fichot \& Benner, 2014). Our budget indicates that $71 \%$ of tDOC $([93+81] / 246$; Figure 5) is mineralized during its first year in the ocean. In Figure 5, refractory tDOC (72 (17-140) $\mathrm{Tg} \mathrm{C} \mathrm{yr}^{-1} \mathrm{or}^{\circ}$ $29 \%$ of the annual tDOC flux to the ocean) refers to a fraction of tDOC having a residence time of more than 1 year in the ocean. This refractory tDOC is either slowly metabolized by microbes, transformed by indirect photochemical reactions (Mopper et al., 1991), and/or transported (1.7 $\mathrm{Tg} \mathrm{C} \mathrm{yr}^{-1}$ ) to the deep ocean (Benner et al., 2005).

\subsection{The Annual Areal Rates of DIC Photoproduction From tDOC in River Plumes}

Our annual areal rates calculated based on equation (2) (Table 5 and Figure 4) are meant to provide an average value for the DIC photoproduction rate $\left(\mathrm{mol} \mathrm{C} \mathrm{m}^{-2} \mathrm{yr}^{-1}\right)$ from tDOC over the entire lifetime of tCDOM in river plumes. The rate estimates are based on values of $\phi_{\lambda}$. Therefore, we first discuss about the $\phi_{\lambda}$ and later about the rates themselves.

Our spectral AQY for DIC photoproduction from tDOC approximates an average photoreactivity of tDOC from its entrance to estuary to its complete removal by photobleaching. This differs from earlier studies, which have characterized $\phi_{\lambda}$ at the site of sample collection (Aarnos et al., 2012; Bélanger et al., 2006; Gao \& Zepp, 1998; Groeneveld et al., 2016; Johannessen \& Miller, 2001; Johannessen et al., 2007; Koehler et al., 2014, 2016; Powers \& Miller, 2015; Reader \& Miller, 2012; Vähätalo \& Wetzel, 2004; Vähätalo et al., 2000; White et al., 2010). Our experimental irradiations photobleached about half of tCDOM and characterize the photoreactivity of tDOC at those sites of river plumes, where solar radiation has photobleached about half of tCDOM. These sites would be, for example, just before the shelf break in Mid-Atlantic Bight (Vodacek et al., 1997) and offshore from the shelf break in the plume of Mississippi River (Fichot \& Benner, 2014). Thus, our $\phi_{\lambda}$ characterize tDOC at the distal parts of river plumes that are considered as the most important sites of photochemical breakdown of tDOC (Hernes \& Benner, 2003; Medeiros et al., 2015; Vodacek et al., 1997). 
Our $\phi_{330}$ values (range of 129 to $335 \mu \mathrm{mol} \mathrm{C} \mathrm{mol} \mathrm{photons}{ }^{-1}$ ) fall into the lower range of reported $\phi_{330}$ values in lakes (Groeneveld et al., 2016; Koehler et al., 2014, 2016; Vähätalo \& Wetzel, 2004; Vähätalo et al., 2000), rivers, and estuaries (Bélanger et al., 2006; Gao \& Zepp, 1998; White et al., 2010), as well as coastal ocean (Aarnos et al., 2012; Johannessen \& Miller, 2001; Johannessen et al., 2007; Powers \& Miller, 2015; Reader \& Miller, 2012). A possible explanation for our low values is the long irradiation time. Because $\phi_{\lambda}$ values decrease with cumulative irradiation doses (Andrews et al., 2000; Vähätalo \& Wetzel, 2004), our $\phi_{\lambda}$ values do not correspond to the highest $\phi_{\lambda}$ values for tDOC upon its discharge into an estuary. For example, our $\phi_{330}$ for tDOC from the Mississippi River $\left(335 \mu \mathrm{mol} \mathrm{C} \mathrm{mol} \mathrm{photons}{ }^{-1}\right.$ ) is expectedly lower than the corresponding pooled mean of $514 \mu \mathrm{mol} \mathrm{C} \mathrm{mol} \mathrm{photons}{ }^{-1}$ for DOC collected from the Gulf of Mexico close to the mouth of the Mississippi River and irradiated for a shorter time period ( $6 \mathrm{~h}$; Powers \& Miller, 2015) compared to the present study ( $39 \mathrm{~h}$ ).

Our median $\phi_{330}$ values for riverine tDOC is $234 \mu \mathrm{mol} \mathrm{C} \mathrm{mol} \mathrm{photons}{ }^{-1}$ and about half of the $479 \mu \mathrm{mol} \mathrm{C} \mathrm{mol}$ photons $^{-1}$ used to estimate the amount of DIC photoproduction in inland waters (Koehler et al., 2014). High $\phi_{330}$ values correlate positively with CDOM, the specific UV absorption coefficient, and the aromaticity of tDOC (Koehler et al., 2016), which are typically highest for tDOC imported freshly from land to inland waters without earlier exposure to solar radiation (Salonen \& Vähätalo, 1994; Xiao et al., 2013, 2015). Additionally, ferric iron associated to tDOC and acidity increase $\phi_{330}$ values in freshwaters (Gu et al., 2017). The mixing of the river waters (1:1) with artificial seawater followed by filtering, as done in this study, transfers tDOC from a freshwater to a seawater matrix, increases $\mathrm{pH}$ to the slightly alkaline values found in the ocean, and potentially flocculates photoreactive components such as iron (Minor et al., 2006). Our $\phi_{\lambda}$ for tDOC from the St. Lawrence River is independent of the matrix (freshwater or seawater) used for its determination. This is in contrast to a decrease in DIC photoproduction after mixing swamp water with seawater (Minor et al., 2006). The difference may be explained by the difference in $\mathrm{pH}$ and the concentration of iron: swamp water had a pH of 4 and an Fe concen-

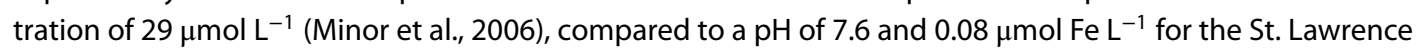
River water (Xiao et al., 2013). It remains unclear whether the seawater matrix used in this study changed $\phi_{\lambda}$ compared to a freshwater matrix in the other rivers, as this was not experimentally addressed, but nevertheless our experimental design addressed those potential changes.

In this study, $\phi_{\lambda}$ values decrease with salinity in the St. Lawrence Estuary, as in the Beaufort Sea (Bélanger et al., 2006), in the Baltic Sea (Aarnos et al., 2012), and in the St. Lawrence Estuary for the photoproduction of CO (Zhang et al., 2006). The dependence of $\phi_{\lambda}$ values on salinity has not always been observed (Powers \& Miller, 2015), or the dependence has included an abrupt change (White et al., 2010). These earlier studies have been conducted in relatively small regions close to river mouths and $\phi_{\lambda}$ values have been determined with short irradiance times ( $8 \mathrm{~h}$, White et al., 2010; $6 \mathrm{~h}$, Powers \& Miller, 2015). These $\phi_{\lambda}$ values possibly trace (i) the complex mixing of riverine $\mathrm{DDOC}$ and marine $\mathrm{DOC}$ close to river mouths, (ii) describe, for example, the flocculation of iron at a certain salinity threshold, or (iii) may also include additional (more local) sources of DOC such as coastal wetlands or sediment pore waters (Powers \& Miller, 2015; White et al., 2010). This study and observations in long transects (greater than a few hundred kilometers) across coastal regions where tDOC is more or less conservatively mixed with marine DOC (Aarnos et al., 2012; Bélanger et al., 2006; Vodacek et al., 1997; Zhang et al., 2006) indicate two end-members in terms of photoreactivity: (1) tDOC at the mouth of river with higher $\phi_{\lambda}$ and (2) marine DOC of open ocean with lower $\phi_{\lambda}$. The mixing of these two end-members together with a decrease in $\phi_{\lambda}$ due to the cumulative exposure of tDOC to solar irradiance can explain the decrease of $\phi_{\lambda}$ with increasing salinity over large spatial scales across the entire span of river plumes.

In this study, the calculated areal rates of DIC photoproduction depend also on the $a_{\mathrm{CDOM}} a_{\mathrm{tot}}^{-1}$ (equation (2)) in the ocean. When ICDOM has lost half of its original absorption in the ocean, it is still expected to dominate the absorption of photolytic solar radiation in river plumes (Bélanger et al., 2013; Johannessen et al., 2003; Taalba et al., 2013), but it does not absorb all photolytic solar radiation as approximated in equation (2). For example, in the river plume of Mackenzie River, the $a_{\mathrm{CDOM}} a_{\mathrm{tot}}^{-1}$ at $330 \mathrm{~nm}$ (equation (2)) is $\sim 0.9$ (Bélanger et al., 2013; Taalba et al., 2013). In the Mid-Atlantic Bight and in the Bering Sea, the ratio of CDOM to the attenuation coefficient at the UVR ranges from 0.86 to 0.97 in coastal to offshore water outside turbid bays (Johannessen et al., 2003). Spectral $a_{\mathrm{CDOM}} a_{\mathrm{tot}}^{-1}$ are poorly available for the river plumes examined in this study and therefore our simplification ( $\left.a_{\mathrm{CDOM}} a_{\mathrm{tot}}^{-1}=1\right)$ likely overestimates the areal DIC photoproduction rates by $<10-15 \%$ (Bélanger et al., 2013; Johannessen et al., 2003; Taalba et al., 2013).

In a strict sense, our DIC photoproduction rates refer to those produced from $\mathrm{DDOC}$ in the matrix of seawater and are not directly comparable to those determined from samples collected from the coastal ocean that also 
include marine DOC (Bélanger et al., 2006; Fichot \& Benner, 2014; Powers \& Miller, 2015). However, tDOC was likely the primary source for photoproduced DIC in the samples collected from the plume of the Mississippi River (Fichot \& Benner, 2014; Powers \& Miller, 2015) and river-influenced coastal Arctic Ocean corresponding to the latitudes of the Lena River plume (Bélanger et al., 2006). In the plume of the Mississippi River, our areal DIC photoproduction rate from tDOC $\left(160 \mathrm{mmol} \mathrm{C} \mathrm{m}^{-2} \mathrm{yr}^{-1}\right)$ is between the two earlier estimates: $73 \mathrm{mmol}$ $\mathrm{C} \mathrm{m}^{-2} \mathrm{yr}^{-1}$ (0.054 Tg C yr${ }^{-1} / 62,068 \mathrm{~km}^{2}$; Fichot \& Benner, 2014) and $296 \mathrm{mmol} \mathrm{C} \mathrm{m}^{-2} \mathrm{yr}^{-1}$ (Powers \& Miller, 2015). Our estimate for the areal DIC photoproduction from tDOC in the Laptev Sea without sea ice ( $52 \mathrm{mmol}$ $\left.\mathrm{C} \mathrm{m}^{-2} \mathrm{yr}^{-1}\right)$ is similar to the corresponding estimates in the Mackenzie Shelf $\left(76 \mathrm{mmol} \mathrm{C} \mathrm{m}^{-2} \mathrm{yr}^{-1}\right)$ and Canada Basin (53 mmol C m$~^{-2} \mathrm{yr}^{-1}$; calculated from Figure 7 in Bélanger et al., 2006). Based on this comparison, our areal rates of DIC photoproduction agree well with those reported earlier.

\subsection{The Area of Ocean Required for the Photochemical Mineralization of tDOC to DIC}

For the calculation of the area required for the photomineralization of $\mathrm{tDOC}$, the annual amount of photomineralized tDOC was divided by an annual average photomineralization rate of $\mathrm{tDOC}$ in each river plume. The calculation thus estimates an annual average area required to photochemically mineralize the photoreactive part of $\mathrm{tDOC}$ flux and photobleach the entire tCDOM flux completely. After a complete photobleaching of $\mathrm{tCDOM}$, a river plume becomes indistinguishable from the low-CDOM background of the open ocean.

This study estimates that the complete photomineralization of photoreactive tDOC from the 10 rivers requires ocean surface area of $9.6 \pm 2.5 \times 10^{6} \mathrm{~km}^{2}$ (Table 6). Assuming that the rivers studied here are representative of the entire global tDOC flux, a simple upscaling (by a factor of 3.56) indicates that $34(25-43) \times 10^{6} \mathrm{~km}^{2}$ of ocean surface are required for the photomineralization of global tDOC flux. This area is less than $12 \%$ of the total ocean surface area $\left(362 \times 10^{6} \mathrm{~km}^{2}\right.$; Easkins \& Sharman, 2010), and slightly more than the surface area over the coastal shelves $\left(24 \times 10^{6} \mathrm{~km}^{2}\right.$; Bauer et al., 2013), but 5-9-times larger than the total area covered by lakes $\left(5 \times 10^{6} \mathrm{~km}^{2}\right.$; Verpoorter et al., 2014). When our estimate for the photomineralization area of tDOC in the ocean is divided by the length of coastline (356,000 km excluding Antarctica without notable rivers; Brinkhoff, 2017), the photomineralization of tDOC is expected to take place an average within a distance of $97 \pm 35 \mathrm{~km}$ from the coastline.

\subsection{Synopsis}

This study provides the first global estimate for the amount of tDOC mineralized photochemically to DIC in the ocean (45 (31-58) $\mathrm{Tg} \mathrm{C} \mathrm{yr}^{-1}$ ) and the area $\left(34(25-43) \times 10^{6} \mathrm{~km}^{2}\right.$ ) required for this process. Our study estimates that the amount of photomineralized tDOC is larger in the ocean than in inland waters (Figure 5). Our tDOC budget estimates that $71 \%$ of riverine tDOC is mineralized through photochemical and biological reactions within 1 year from its discharge to the ocean (Figure 5). Nearly half (47\%) of this mineralization of tDOC is estimated to be caused by the photochemical production of labile DOC and DIC (Figure 5). In order to improve our estimates, the photomineralization areas (Table 6) could be quantitatively compared to the distribution of CDOM in the coastal ocean obtained with remote sensing methodology. In addition a better knowledge of tCDOM fluxes should put tighter constraints on the amounts of photomineralized tDOC in the ocean.

\section{References}

Aarnos, H., Ylöstalo, P., \& Vähätalo, A. V. (2012). Seasonal phototransformation of dissolved organic matter to ammonium, dissolved inorganic carbon, and labile substrates supporting bacterial biomass across the Baltic Sea. Journal of Geophysical Research, $117, \mathrm{G} 01004$. https://doi.org/10.1029/2010JG001633

Amon, R. M. W., \& Benner, R. (1996). Photochemical and microbial consumption of dissolved organic carbon and dissolved oxygen in the Amazon River system. Geochimica et Cosmochimica Acta, 60(10), 1783-1792. https://doi.org/10.1016/0016-7037(96)00055-5

Andrews, S. S., Caron, S., \& Zarioul, O. C. (2000). Photochemical oxygen consumption in marine waters: A major sink for colored dissolved organic matter. Limnology and Oceanography, 45(2), 267-277. https://doi.org/10.4319/lo.2000.45.2.0267

Asmala, E., Bowers, D. G., Autio, R., Kaartokallio, H., \& Thomas, D. N. (2014). Qualitative changes of riverine dissolved organic matter at low salinities due to flocculation. Journal of Geophysical Research: Biogeosciences, 119, 1919-1933. https://doi.org/10.1002/2014JG002722

Bauer, J. E., Cai, W.-J., Raymond, P. A., Bianchi, T. S., Hopkinson, C. S., \& Regnier, P. A. G. (2013). The changing carbon cycle of the coastal ocean. Nature, 504, 61-70. https://doi.org/10.1038/nature12857

Bélanger, S., Cizmeli, S. A., Ehn, J., Matsuoka, A., Doxaran, D., Hooker, S., \& Babin, M. (2013). Light absorption and partitioning in Arctic Ocean surface waters: Impact of multiyear ice melting. Biogeosciences, 10(10), 6433-6452. https://doi.org/10.5194/bg-10-6433-2013

Bélanger, S., Xie, H., Krotkov, N., Larouche, P., Vincent, W. F., \& Babin, M. (2006). Photomineralization of terrigenous dissolved organic matter in Arctic coastal waters from 1979 to 2003 : Interannual variability and implications of climate change. Global Biogeochemical Cycles, 20, GB4005. https://doi.org/10.1029/2006GB002708

Benner, R., Louchouarn, P., \& Amon, R. M. W. (2005). Terrigenous dissolved organic matter in the Arctic Ocean and its transport to surface and deep waters of the North Atlantic. Global Biogeochemical Cycles, 19, GB2025. https://doi.org/10.1029/2004GB002398

Bertilsson, S., \& Tranvik, L. (2000). Photochemical transformation of dissolved organic matter in lakes. Limnology and Oceanography, 45(4), 753-762. https://doi.org/10.4319/lo.2000.45.4.0753 
Bertilsson, S., Stepanauskas, R., Cuadros-Hansson, R., Graneli, W., Wikner, J., \& Tranvik, L. (1999). Photochemically induced changes in bioavailable carbon and nitrogen pools in a boreal watershed. Aquatic Microbial Ecology, 19, 47-56. https://doi.org/10.3354/ame019047 Blough, N. V., \& Del Vecchio, R. (2002). Biogeochemistry of Marine Dissolved Organic Matter (pp. 509-546). New York, NY: Elsevier. https://doi.org/10.1016/B978-012323841-2/50012-9

Bricaud, A., Morel, A., \& Prieur, L. (1981). Absorption by dissolved organic matter of thesea (yellow substance) in the UV and visible domains. Limnology and Oceanography, 26(1), 43-53. https://doi.org/10.4319/lo.1981.26.1.0043

Brinkhoff, T. (2017). CIA world factbook. Coastline Lengths.

Cai, W.-J. (2011). Estuarine and coastal ocean carbon paradox: $\mathrm{CO}_{2}$ sinks or sites of terrestrial carbon incineration? Annual Review of Marine Science, 3(1), 123-145. https://doi.org/10.1146/annurev-marine-120709-142723

Cao, F., Medeiros, P. M., \& Miller, W. L. (2016). Optical characterization of dissolved organic matter in the Amazon River plume and the adjacent ocean: Examining the relative role of mixing, photochemistry, and microbial alterations. Marine Chemistry, 186, $178-188$. https://doi.org/10.1016/j.marchem.2016.09.007

Catalá, T. S., Reche, I., Álvarez, M., Khatiwala, S., Guallart, E. F., Benítez-Barrios, V. M., ... Álvarez-Salgado, X. A. (2015). Water mass age and aging driving chromophoric dissolved organic matter in the dark global ocean. Global Biogeochemical Cycles, 29, 917-934. https://doi.org/10.1002/2014GB005048

Cauwet, G. (2002). DOM in the coastal zone. In D. A. Hansell \& C. A. Carlson (Eds.), Biogeochemistry of marine dissolved organic matter (chap. 12, pp. 579-609). San Diego: Academic Press. https://doi.org/10.1016/B978-012323841-2/50014-2

Chen, J., Gu, B., LeBoeuf, E. J., Pan, H., \& Dai, S. (2002). Spectroscopic characterization of the structural and functional properties of natural organic matter fractions. Chemosphere, 48(1), 59-68. https://doi.org/10.1016/S0045-6535(02)00041-3

Coles, V. J., Brooks, M. T., Hopkins, J., Stukel, M. R., Yager, P. L., \& Hood, R. R. (2013). The pathways and properties of the Amazon river plume in the tropical North Atlantic Ocean. Journal of Geophysical Research: Oceans, 118, 6894-6913. https://doi.org/10.1002/2013JC008981

Cory, R. M., Ward, C. P., Crump, B. C., \& Kling, G. W. (2014). Sunlight controls water column processing of carbon in arctic fresh waters. Science, 345(6199), 925-928. https://doi.org/10.1126/science.1253119

Coynel, A., Seyler, P., Etcheber, H., Meybeck, M., \& Orange, D. (2005). Spatial and seasonal dynamics of total suspended sediment and organic carbon species in the Congo River. Global Biogeochemical Cycles, 19, GB4019. https://doi.org/10.1029/2004GB002335

Eakins, B., \& Sharman, G. (2010). Volumes of the world's oceans from ETOPO1. Boulder, CO: NOAA National Geophysical Data Center.

Fichot, C. G., \& Benner, R. (2014). The fate of terrigenous dissolved organic carbon in a river-influenced ocean margin. Global Biogeochemical Cycles, 28, 300-318. https://doi.org/10.1002/2013GB004670

Gao, H., \& Zepp, R. G. (1998). Factors influencing photoreactions of dissolved organic matter in a coastal river of the Southeastern United States. Environmental Science \& Technology, 32(19), 2940-2946. https://doi.org/10.1021/es9803660

Groeneveld, M. M., Tranvik, L. J., \& Koehler, B. (2016). Photochemical mineralisation in a boreal brown water lake: Considerable temporal variability and minor contribution to carbon dioxide production. Biogeosciences, 13, 3931-3943. https://doi.org/ 10.5194/bg-13-3931-2016

Gu, Y., Lensu, A., Perämäki, S., Ojala, A., \& Vähätalo, A. V. (2017). Iron and pH regulating the photochemical mineralization of dissolved organic carbon. Omega, 2(5), 1905-1914. https://doi.org/10.1021/acsomega.7b00453

Gustafsson, Ö, Widerlund, A., Andersson, P. S., Ingri, J., Roos, P., \& Ledin, A. (2000). Colloid dynamics and transport of major elements through a boreal river - Brackish bay mixing zone. Marine Chemistry, 71(1-2), 1-21. https://doi.org/10.1016/S0304-4203(00)00035-9

Hatzianastassiou, N., Matsoukas, C., Fotiadi, A., Pavlakis, K. G., Drakakis, E., Hatzidimitriou, D., \& Vardavas, I. (2005). Global distribution of Earth's surface shortwave radiation budget. Atmospheric Chemistry and Physics Discussions, 5(4), 4545-4597. https://doi.org/ 10.5194/acpd-5-4545-2005

Hedges, J. I., Keil, R. G., \& Benner, R. (1997). What happens to terrestrial organic matter in the ocean? Organic Geochemistry, $27(56), 195-212$. https://doi.org/10.1016/S0146-6380(97)00066-1

Hernes, P. J., \& Benner, R. (2003). Photochemical and microbial degradation of dissolved lignin phenols: Implications for the fate of terrigenous dissolved organic matter in marine environments. Journal of Geophysical Research, 108(c9), 3291. https://doi.org/ $10.1029 / 2002 J C 001421$

Holmes, R. M., McClelland, J. W., Raymond, P. A., Frazer, B. B., Peterson, B. J., \& Stieglitz, M. (2008). Lability of DOC transported by Alaskan rivers to the Arctic Ocean. Geophysical Research Letters, 35, L03402. https://doi.org/10.1029/2007GL032837

Jaffé, R., Ding, Y., Niggemann, J., Vähätalo, A. V., Stubbins, A., Spencer, R. G. M., ... Dittmar, T. (2013). Global charcoal mobilization from soils via dissolution and riverine transport to the oceans. Science, 340(6130), 345-347. https://doi.org/10.1126/science.1231476

Jankowski, J. J., Kieber, D. J., Mopper, K., \& Neale, P. J. (2000). Development and intercalibration of ultraviolet solar actinometers. Photochemistry and Photobiology, 71(4), 431-440. https://doi.org/10.1562/0031-8655(2000)0710431DAIOUS2.0.CO2

Johannessen, S. C., \& Miller, W. L. (2001). Quantum yield for the photochemical production of dissolved inorganic carbon in seawater. Marine Chemistry, 76(4), 271-283. https://doi.org/10.1016/S0304-4203(01)00067-6

Johannessen, S. C., Miller, W., \& Cullen, J. (2003). Calculation of UV attenuation and colored dissolved organic matter absorption spectra from measurements of ocean color. Journal of Geophysical Research, 108(C9), 3301. https://doi.org/10.1029/2000JC000514

Johannessen, S. C., Peña, M. A., \& Quenneville, M. L. (2007). Photochemical production of carbon dioxide during a coastal phytoplankton bloom. Estuarine, Coastal and Shelf Science, 73(1-2), 236-242. https://doi.org/10.1016/j.ecss.2007.01.006

Jørgensen, L., Stedmon, C. A., Granskog, M. A., \& Middelboe, M. (2014). Tracing the long-term microbial production of recalcitrant fluorescent dissolved organic matter in seawater. Geophysical Research Letters, 41, 2481-2488. https://doi.org/10.1002/2014GL059428

Kester, D. R., Duedall, I. W., Connors, D. N., \& Pytkowic, R. (1967). Preparation of artificial seawater. Limnology and Oceanography, 12(1), 176-179. https://doi.org/10.4319/lo.1967.12.1.0176

Kieber, R. J., Zhou, X., \& Mopper, K. (1990). Formation of carbonyl compounds from UV-induced photodegradation of humic substances in natural waters: Fate of riverine carbon in the sea. Limnology and Oceanography, 35(7), 1503-1515. https://doi.org/10.4319/lo.1990.35.7.1503

Kiehl, J. T., \& Trenberth, K. E. (1997). Earth's annual global mean energy budget. Bulletin of the American Meteorological Society, 78(2), 197-208. https://doi.org/10.1175/1520-0477(1997)078<0197:EAGMEB > 2.0.CO;2

Koehler, B., von Wachenfeldt, E., Kothawala, D., \& Tranvik, L. J. (2012). Reactivity continuum of dissolved organic carbon decomposition in lake water. Journal of Geophysical Research, 117, G01024. https://doi.org/10.1029/2011JG001793

Koehler, B., Broman, E., \& Tranvik, L. J. (2016). Apparent quantum yield of photochemical dissolved organic carbon mineralization in lakes. Limnology and Oceanography, 61(6), 2207-2221. https://doi.org/10.1002/Ino.10366

Koehler, B., Landelius, T., Weyhenmeyer, G. A., Machida, N., \& Tranvik, L. J. (2014). Sunlight-induced carbon dioxide emissions from inland waters. Global Biogeochemical Cycles, 28, 696-711. https://doi.org/10.1002/2014GB004850 
Korshin, G. V., Li, C.-W., \& Benjamin, M. M. (1997). Organic matter through UV spectroscopy. Water Research, $31(7), 1787-1795$. https://doi.org/10.1016/S0043-1354(97)00006

Lalonde, K., Vähätalo, A. V., \& Gélinas, Y. (2014). Revisiting the disappearance of terrestrial dissolved organic matter in the ocean: A $\delta^{13} \mathrm{C}$ study. Biogeosciences, 11(13), 3707-3719. https://doi.org/10.5194/bg-11-3707-2014

Medeiros, P. M., Seidel, M., Ward, N. D., Carpenter, E. J., Gomes, H. R., Niggemann, J., ... Dittmar, T. (2015). Fate of the Amazon River dissolved organic matter in the tropical Atlantic Ocean. Global Biogeochemical Cycles, 29, 677-690. https://doi.org/10.1002/2015GB005115

Medeiros, P. M., Babcock-Adams, L., Seidel, M., Castelao, R. M., Di lorio, D., Hollibaugh, J. T., \& Dittmar, T. (2017). Export of terrigenous dissolved organic matter in a broad continental shelf. Limnology and Oceanography, 62(4), 1718-1731. https://doi.org/10.1002/lno.10528

Meybeck, M. (1982). Carbon, nitrogen, and phosphorus transport by world rivers. American Journal of Science, $282(4), 401-450$. https://doi.org/10.2475/ajs.282.4.401

Miller, W. L., \& Moran, M. A. (1997). Interaction of photochemical and microbial processes in the degradation of refractory dissolved organic matter from a coastal marine environment. Limnology and Oceanography, 42(6), 1317-1324. https://doi.org/10.4319/lo.1997.42.6.1317

Miller, W. L., \& Zepp, R. G. (1995). Photochemical production of dissolved inorganic carbon from terrestrial organic matter: Significance to the oceanic organic carbon cycle. Geophysical Research Letters, 22(4), 417-420. https://doi.org/10.1029/94GL03344

Miller, W. L., Moran, M. A., \& Sheldon, W. M. (2002). Determination of apparent quantum yield spectra for the formation of biologically labile photoproducts. Limnology and Oceanography, 47(2), 343-352. https://doi.org/10.4319/lo.2002.47.2.0343

Milliman, J. D., \& Farnsworth, K. L. (2011), River discharge to the coastal ocean: A global synthesis (Vol. 24, pp. 143-144). Cambridge: Cambridge University Press. https://doi.org/10.1017/CBO9780511781247

Minor, E. C., Pothen, J., Dalzell, B. J., Abdulla, H., \& Mopper, K. (2006). Effects of salinity changes on the photodegradation and ultraviolet-visible absorbance of terrestrial dissolved organic matter. Limnology and Oceanography, $51(5), 2181-2186$. https://doi.org/10.4319/lo.2006.51.5.2181

Mopper, K., Zhou, X., Kieber, R. J., Kieber, D. J., Sikorski, R. J., \& Jones, R. D. (1991). Photochemical degradation of dissolved organic carbon and its impact on the oceanic carbon cycle. Nature, 353(6339), 60-62. https://doi.org/10.1038/353060a0

Nelson, N. B., \& Siegel, D. A. (2013). The global distribution and dynamics of chromophoric dissolved organic matter. Annual Review of Marine Science, 5, 447-476. https://doi.org/10.1146/annurev-marine-120710-100751

Nelson, N. B., Siegel, D. A., \& Michaels, a. F. (1998). Seasonal dynamics of colored dissolved material in the Sargasso Sea. Deep-Sea Research Part l: Oceanographic Research Papers, 45(6), 931-957. https://doi.org/10.1016/S0967-0637(97)00106-4

Powers, L. C., \& Miller, W. L. (2015). Photochemical production of $\mathrm{CO}$ and $\mathrm{CO}_{2}$ in the Northern Gulf of Mexico: Estimates and challenges for quantifying the impact of photochemistry on carbon cycles. Marine Chemistry, 171, 21-35. https://doi.org/ 10.1016/j.marchem.2015.02.004

Pullin, M. J., Bertilsson, S., Goldstone, J. V., \& Voelker, B. M. (2004). Effects of sunlight and hydroxyl radical on dissolved organic matter: Bacterial growth efficiency and production of carboxylic acids and other substrates. Limnology and Oceanography, 49(6), $2011-2022$. https://doi.org/10.4319/lo.2004.49.6.2011

Raymond, P. A., \& Spencer, R. G. M. (2014). Riverine DOM: Biogeochemistry of marine dissolved organic matter (2nd ed., pp. 509-533). New York, NY: Academic Press. https://doi.org/10.1016/B978-0-12-405940-5.00011-X

Reader, H. E., \& Miller, W. L. (2012). Variability of carbon monoxide and carbon dioxide apparent quantum yield spectra in three coastal estuaries of the South Atlantic Bight. Biogeosciences, 9(11), 4279-4294. https://doi.org/10.5194/bg-9-4279-2012

Regnier, P., Friedlingstein, P., Ciais, P., Mackenzie, F., Gruber, N., Janssens, I., ... Thullner, M. (2013). Anthropogenic perturbation of the carbon fluxes from land to ocean. Nature Geoscience, 6, 597-607. https://doi.org/10.1038/ngeo1830

Riedel, T., Zark, M., Vähätalo, A. V., Niggemann, J., Spencer, R. G. M., Hernes, P. J., \& Dittmar, T. (2016). Molecular signatures of biogeochemical transformations in dissolved organic matter from ten world rivers. Frontiers in Earth Science, 4(85), 1-16. https://doi.org/10.3389/feart.2016.00085

Rossel, P. E., Vähätalo, A. V., Witt, M., \& Dittmar, T. (2013). Molecular composition of dissolved organic matter from a wetland plant (Juncus effusus) after photochemical and microbial decomposition (1.25 yr): Common features with deep sea dissolved organic matter. Organic Geochemistry, 60, 62-71. https://doi.org/10.1016/j.orggeochem.2013.04.013

Salonen, K. (1981). Rapid and precise determination of total inorganic carbon and some gases in aqueous solutions. Water Research, 15(4), 403-406. https://doi.org/10.1016/0043-1354(81)90049-X

Salonen, K., \& Vähätalo, A. (1994). Photochemical mineralisation of dissolved organic matter in Lake Skjervatjern. Environment International, 20(3), 307-312. https://doi.org/10.1016/0160-4120(94)90114-7

Shank, G. C., Zepp, R. G., Vähätalo, A., Lee, R., \& Bartels, E. (2010). Photobleaching kinetics of chromophoric dissolved organic matter derived from mangrove leaf litter and floating Sargassum colonies. Marine Chemistry, 119(1-4), 162-171. https://doi.org/ 10.1016/j.marchem.2010.01.003

Sholkovitz, E. R. (1976). Flocculation of dissolved organic and inorganic matter during the mixing of river water and seawater. Geochimica et Cosmochimica Acta, 40(7), 831-845. https://doi.org/10.1016/0016-7037(76) 90035-1

Sobek, S., Tranvik, L., \& Prairie, Y. (2007). Patterns and regulation of dissolved organic carbon: An analysis of 7,500 widely distributed lakes. Limnology and Oceanography, 52(3), 1208-1219. https://doi.org/10.4319/lo.2007.52.3.1208

Søndergaard, M., \& Middelboe, M. (1995). A cross-system analysis of labile dissolved organic carbon. Marine Ecology Progress Series, 118, 283-294. https://doi.org/10.3354/meps118283

Spencer, R. G. M., Aiken, G. R., Dornblaser, M. M., Butler, K. D., Holmes, R. M., Fiske, G., .. Stubbins, A. (2013). Chromophoric dissolved organic matter export from U.S. rivers. Geophysical Research Letters, 40, 1575-1579. https://doi.org/10.1002/grl.50357

Spencer, R. G. M., Stubbins, A., Hernes, P. J., Baker, A., Mopper, K., Aufdenkampe, A. K., ... Six, J. (2009). Photochemical degradation of dissolved organic matter and dissolved lignin phenols from the Congo River. Journal of Geophysical Research, 114, G03010. https://doi.org/10.1029/2009JG000968

Stedmon, C., Amon, R., Rinehart, A., \& Walker, S. (2011). The supply and characteristics of colored dissolved organic matter (CDOM) in the Arctic Ocean: Pan Arctic trends and dierences. Marine Chemistry, 124(1-4), 108-118. https://doi.org/10.1016/j.marchem.2010.12.007

Swan, C. M., Nelson, N. B., Siegel, D. A., \& Kostadinov, T. S. (2012). The effect of surface irradiance on the absorption spectrum of chromophoric dissolved organic matter in the global ocean. Deep Sea Research Part I: Oceanographic Research Papers, 63, 52-64. https://doi.org/10.1016/j.dsr.2012.01.008

Taalba, A., Xie, H., Scarratt, M. G., Belanger, S., \& Levasseur, M. (2013). Photooxidation of dimethylsulde (DMS) in the Canadian Arctic. Biogeosciences, 10(11), 6793-6806. https://doi.org/10.5194/bg-10-6793-2013

Vähätalo, A., \& Järvinen, M. (2007). Photochemically produced bioavailable nitrogen from biologically recalcitrant dissolved organic matter stimulates production of a nitrogen-limited microbial food web in the Baltic Sea. Limnology and Oceanography, 52(1), $132-143$. https://doi.org/10.4319/lo.2007.52.1.0132 
Vähätalo, A., Salkinoja-salonen, M., Taalas, P., \& Salonen, K. (2000). Spectrum of the quantum yield for photochemical mineralization of dissolved organic carbon in a humic lake. Limnology and Oceanography, 45(3), 664-676. https://doi.org/10.4319/lo.2000.45.3.0664

Vähätalo, A. V., \& Wetzel, R. G. (2004). Photochemical and microbial decomposition of chromophoric dissolved organic matter during long (months-years) exposures. Marine Chemistry, 89(1-4), 313-326. https://doi.org/10.1016/j.marchem.2004.03.010

Vähätalo, A. V., \& Zepp, R. G. (2005). Photochemical mineralization of dissolved organic nitrogen to ammonium in the Baltic Sea. Environmental Science \& Technology, 39(18), 6985-6992. https://doi.org/10.1021/es050142z

Vähätalo, A. V., Salonen, K., Münster, U., Järvinen, M., \& Wetzel, R. G. (2003). Photochemical transformation of allochthonous organic matter provides bioavailable nutrients in a humic lake. Archiv fur Hydrobiologie, 156(3), 287-314. https://doi.org/ 10.1127/0003-9136/2003/0156-0287

Vähätalo, A. V., Salonen, K., Salkinoja-Salonen, M., \& Hatakka, A. (1999). Photochemical mineralization of synthetic lignin in lake water indicates enhanced turnover of aromatic organic matter under solar radiation. Biodegradation, 10(6), 415-420. https://doi.org/10.1023/A:1008322520299

Vähätalo, A. V., Aarnos, H., \& Mäntyniemi, S. (2010). Biodegradability continuum and biodegradation kinetics of natural organic matter described by the beta distribution. Biogeochemistry, 100(1-3), 227-240. https://doi.org/10.1007/s10533-010-9419-4

Vähätalo, A. V., Aarnos, H., Hoikkala, L., \& Lignell, R. (2011). Photochemical transformation of terrestrial dissolved organic matter supports hetero- and autotrophic production in coastal waters. Marine Ecology Progress Series, 423, 1-14. https://doi.org/10.3354/meps09010

Vähätalo, A. V. A., \& Wetzel, R. R. G. (2008). Long-term photochemical and microbial decomposition of wetland-derived dissolved organic matter with alteration of ${ }^{13} \mathrm{C}:{ }^{12} \mathrm{C}$ mass ratio. Limnology and Oceanography, 53(4), 1387-1392. https://doi.org/10.4319//o.2008.53.4.1387

Verpoorter, C., Kutser, T., Seekell, D. A., \& Tranvik, L. J. (2014). A global inventory of lakes based on high-resolution satellite imagery. Geophysical Research Letters, 41, 6396-6402. https://doi.org/10.1002/2014GL060641

Vodacek, A., Blough, N. V., Degrandpre, M. D., Peltzer, E. T., \& Nelson, R. K. (1997). Seasonal variation of CDOM and DOC in the Middle Atlantic Bight: Terrestrial inputs and photooxidation. Limnology and Oceanography, 42(4), 674-686. https://doi.org/10.4319/lo.1997.42.4.0674

Wagner, S., Riedel, T., Niggemann, J., Vähätalo, A. V., Dittmar, T., \& Jaffe, R. (2015). Linking the molecular signature of heteroatomic dissolved organic matter to watershed characteristics in world rivers. Environmental Science \& Technology, 49(23), 13798-13806. https://doi.org/10.1021/acs.est.5b00525

Ward, N. D., Keil, R. G., Medeiros, P. M., Brito, D. C., Cunha, A. C., Dittmar, T., ... Richey, J. E. (2013). Degradation of terrestrially derived macromolecules in the Amazon River. Nature Geoscience, 6(7), 530-533. https://doi.org/10.1038/ngeo1817

White, E. M., Kieber, D. J., Sherrard, J., Miller, W. L., \& Mopper, K. (2010). Carbon dioxide and carbon monoxide photoproduction quantum yields in the Delaware Estuary. Marine Chemistry, 118(1-2), 11-21. https://doi.org/10.1016/j.marchem.2009.10.001

Xiao, Y.-H., Räike, A., Hartikainen, H., \& Vähätalo, A. V. (2015). Iron as a source of color in river waters. Science of The Total Environment, 536, 914-923. https://doi.org/10.1016/j.scitotenv.2015.06.092

Xiao, Y.-H., Sara-Aho, T., Hartikainen, H., \& Vähätalo, A. V. (2013). Contribution of ferric iron to light absorption by chromophoric dissolved organic matter. Limnology and Oceanography, 58(2), 653-662. https://doi.org/10.4319/lo.2013.58.2.0653

Zhang, Y., Xie, H., Chen, G., Lawrence, S., \& Chen, G. (2006). Factors affecting the efficiency of carbon monoxide photoproduction in the St. Lawrence estuarine system (Canada). Environmental Science \& Technology, 40(24), 7771-7777. https://doi.org/10.1021/es0615268 